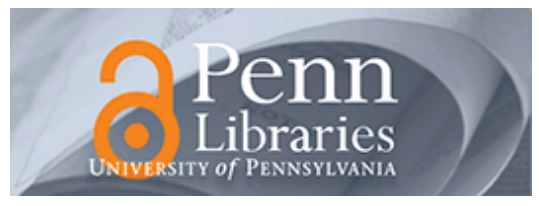

University of Pennsylvania

ScholarlyCommons

Finance Papers

Wharton Faculty Research

2002

\title{
Demand Curves and the Pricing of Money Management
}

\section{Susan Elizabeth Kerr Christoffersen}

David K. Musto

University of Pennsylvania

Follow this and additional works at: https://repository.upenn.edu/fnce_papers

Part of the Finance Commons, and the Finance and Financial Management Commons

\section{Recommended Citation}

Christoffersen, S., \& Musto, D. K. (2002). Demand Curves and the Pricing of Money Management. Review of Financial Studies, 15 (5), 1499-1524. http://dx.doi.org/10.1093/rfs/15.5.1499

This paper is posted at ScholarlyCommons. https://repository.upenn.edu/fnce_papers/322

For more information, please contact repository@pobox.upenn.edu. 


\title{
Demand Curves and the Pricing of Money Management
}

\author{
Abstract \\ One reason why funds charge different prices to their investors is that they face different demand curves. \\ One source of differentiation is asset retention: Performance-sensitive investors migrate from worse to \\ better prospects, taking their performance sensitivity with them. In the cross-section we show that past \\ attrition significantly influences the current pricing of retail but not institutional funds. In time-series we \\ show that the repricing of retail funds after merging in new shareholders is predicted by the estimated \\ effect on its demand curve. This result is robust to other influences on repricing, including asset and \\ account-size changes. \\ Disciplines \\ Finance | Finance and Financial Management
}




\section{Demand Curves and the Pricing of Money Management"}

\author{
Susan Christoffersen \\ Finance Department \\ McGill University \\ 1001 Sherbrooke Street West \\ Montreal, Quebec H3A 1G5 \\ christos@management.mcgill.ca \\ (514) 398-4012
}

\author{
David K. Musto \\ Finance Department \\ Wharton School, U. Penn. \\ 3620 Locust Walk \\ Philadelphia PA 19104 \\ musto@wharton.upenn.edu \\ (215) 898-4239
}

First Version September 1998

This Revision November 23, 2001

\footnotetext{
*The authors thank Carl Ackermann, Franklin Allen, Peter Burns, Peter Christoffersen, Roger Edelen, Wayne Ferson, Will Goetzmann, Bruce Grundy, Jason Heinhorst, Vince Warther, and seminar participants at the Conference on Financial Economics and Accounting at NYU, the Western Finance Association meeting in Santa Monica, London Business School, McGill, the University of Calgary, the University of Washington, Wharton and Yale, an anonymous referee and Maureen O'Hara (the editor) for helpful comments and suggestions. Financial support from the Wharton Financial Institutions Center and SSHRC and FCAR is gratefully acknowledged. Research assistance from Eric Turner and John Bromley was helpful in matching databases. Any remaining errors are our responsibility. Address correspondence to: Susan Christoffersen, Faculty of Management, McGill University, 1001 Sherbrooke St. West, Montreal, QC, Canada, H3A-1G5, or e-mail: christos@management.mcgill.ca, or phone: (514) 398-4012.
} 


\section{ABSTRACT \\ Demand Curves and the Pricing of Money Management}

One reason why funds charge different prices to their investors is that they face different demand curves. One source of differentiation is asset retention: performance-sensitive investors migrate from worse to better prospects, taking their performance-sensitivity with them. In the cross section we show that past attrition significantly influences the current pricing of retail, but not institutional, funds. In time series we show that the repricing of retail funds after merging in new shareholders is predicted by the estimated effect on its demand curve. This result is robust to other influences on re-pricing, including asset and account-size changes. 
What accounts for the dispersion of mutual-fund fees? In principle it could reflect dispersion of performance expectations, but the finance literature does not support that view. Most of the literature considers equity funds, where ex post performance apparently goes the wrong way: the worst performers charge the highest average fees (Carhart (1997)), and the most expensive funds deliver the worst average net performance (Gruber (1996)). But since equity-fund returns are so noisy and risk adjustments are so ambiguous, it is worth looking instead at the money-fund industry, and there the evidence is qualitatively similar but much stronger. Over a given period, money funds realize very similar gross returns but deliver very different net returns to investors because the dispersion of their fees is so wide (see, e.g., Bogle (1994), Fredman and Wiles (1998), Domian and Reichenstein (1998)). With no reasonable basis for expecting differential performance, why do these funds' investors pay differential fees? We consider the possibility that the difference lies in the investors themselves.

A consumer brings her own tastes, beliefs and assets to the financial market, and these imply a personal demand curve for mutual-fund shares. On the other side of the market, a given mutual fund imputes consumers' demand curves into its pricing but all the hundreds of millions of consumers do not have to enter this equation unconditionally and identically. The fund would intuitively have relatively more access to a much smaller subset of consumers, so that their demand curves enter relatively more. This would be a trivial point if the subsets of the various funds were unbiased samples, but there are reasons to suspect they are not. The one we primarily focus on here is the finding by Gruber (1996) and Zheng (1999) that investors vary in their responses to changes in funds' prospects. Some money flows from worse to better prospects but other 
money does not, increasing the density of performance-sensitive investors in the betterprospect funds and performance-insensitive investors in the others. Since fees are simply reductions of performance, this has a straightforward pricing implication: investors remaining in the worse prospects should be charged more.

This logic is borrowed from the home-mortgage literature (e.g. Schwartz and Torous (1989)) which observes that the mortgagors who remain in a fixed-rate pool after a refinancing opportunity have self-selected. They are relatively less sensitive to refinancing opportunities so the present value of their future payments (credit-risk issues aside) is at a premium. The better was the opportunity, the greater the self-selection and the bigger the premium. This well-known element of consumers' liability management could extend to their assets, and our primary goal is to see if it does. Our secondary goal is to see if demand-curve variation in general, regardless of source, explains price variation.

We test the demand-side pricing model on the American money-fund industry. This venue choice serves several purposes. As indicated above, the similarity of gross returns obviates performance-based explanations of fee differences and makes relative prospects easy to measure accurately. We maximize this benefit by focusing on a single subcategory, the largest, of retail money funds. Also, we need funds that can adjust fees up or down at will, which describes most money funds due to the widespread practice of fee-waiving (Christoffersen (2001)). And finally, we don't want interference from the capital-gains tax.

The empirical tests come in three groups. In the first group we establish the basic dynamics of the subcategory we focus on, some of which are familiar from elsewhere. 
The funds charge a wide range of fees, their relative returns are driven almost exclusively by relative fees and are highly persistent, and their net flows are sensitive to past returns in the region of high past returns. Cross-sectional regressions find no relation between fees and service offerings.

The second group directly tests the model, which we call the seasoning model, inspired by Gruber (1996) and Zheng (1999). In parallel with the mortgage-pool example, we test cross-sectionally whether retail investors who remain after relatively more attrition pay relatively higher fees. We find that they do, whether or not we control for fund size. An investor who remains after $50 \%$ attrition pays about $10 \mathrm{bp}(\mathrm{bp}=$ basis point, $1 / 100$ or $1 \%$ ) more. We show this is not true for institutional investors; if anything, they are charged less after attrition. The cross section of fees also relates significantly to the cross section of distribution methods. Contractual fees are about the same for broker- and directly-distributed funds, but the directly-distributed funds choose to charge significantly less, consistent with the evidence in Capon, Fitzsimons and Prince (1996) and Alexander, Jones and Nigro (1998) that the investors who arrive through brokers are significantly less price-sensitive.

Finally, we test for demand-curve effects in general by analyzing the re-pricing of funds after mergers. The useful feature of a merger is that it implies a discrete shift in the surviving fund's demand curve, i.e. the aggregate demand of its investor base, while controlling for other potentially important features of the surviving fund. After merging in the target's shareholders, the surviving fund faces its previous demand curve combined with the demand curve of the target fund, but a fund share is essentially the same as before, assuming service quality remains constant. We solve a simple model that predicts 
a surviving fund's re-pricing by backing out estimates of the separate funds' demand curves and picking the profit-maximizing price along their combination.

Looking across a sample of mergers from 1988 through 1997, we find that the demand-side model explains a significant portion of price revisions. This holds even when we control for the expected re-pricing due to the change in fund size and average account size across the merger. The result is especially strong when the acquiring funds have pre-merger fee waivers, consistent with their wider latitude to re-price frictionlessly. Unconditionally, mergers appear as likely to raise prices as lower them, but our measures of demand-curve innovations reliably identify which funds will charge more or less, and by how much.

The rest of the paper is in five sections. Section I describes the data. Section II covers the literature and the important features of the money-fund industry, and motivates our hypothesis. Section III tests the cross section of fees for sensitivity to past attrition and to distribution channels, Section IV solves the demand-curve model and tests it on time series of prices around mergers, and Section V summarizes and concludes.

\section{Data}

The database for the empirical tests combines data from several sources. The first source is the weekly newsletter Money Fund Report (MFR) published by IBC/Donoghue. Among other things, it reports the assets under management and seven-day yield (total return to investors over the past 7 days, times 365/7) as of each Tuesday for all funds that voluntarily report. The publishers estimate that over $95 \%$ of funds report, and the data cover November 1987 through July 1997. The largest category of funds tracked is what MFR calls Tier 1 and Tier 2 retail funds: retail funds that invest in the whole range of 
money market instruments (i.e. not restricted to municipal issues or some combination of Treasury and Agency issues). As of August 31, 1998, there were 293 such funds, managing $\$ 538$ Billion (out of the $\$ 1.229$ Trillion managed by all money funds). We also use the MFR data on institutional (i.e. intended for institutional shareholders) Tier 1 and Tier 2 funds, of which there were 171 on August 31, 1998, managing \$223 Billion. This data are not survivor-biased; for each week, it includes every fund that chose to report that week.

The publishers inquired after each fund that stopped reporting, and identified all the funds that stopped because they had merged into other funds. They identified 47 mergers of Tier 1 or Tier 2 retail funds into other Tier 1 or Tier 2 retail funds between 1987 and 1997. These mergers, listed in the Appendix, are the ones we study below. In addition to tracking asset size and yield for each fund, IBC Donoghue separately provided us with pre- and post-merger average account size for 40 of the surviving funds. We also acquired average account data from a 1995 industry survey by Lipper reporting average account size, total net assets and fees of 72 retail Tier 1 and Tier 2 money funds.

The MFR data do not include expense ratios, so we collected those from elsewhere. Most of the expense data is from Lipper; for each fund they cover we have the total fee charged to investors and the year-end assets under management for each fiscal year they have been tracked. These figures are the actual fees paid by investors, so they combine advisory and administrative fees and are net of any expense waivers applied by the fund. We matched the Lipper and MFR databases by hand, checking that the time series of assets under management correspond. Some of the mergers occurred too late for our database to show a fee for a fiscal year after the merger. In these cases, we looked up 
the fee in the SEC filings available on LEXIS/NEXIS. Pre-merger fees for two funds were not in the Lipper data or the SEC filings, so most of the tests analyze 45 of the 47 mergers. Also from Lipper we have the pre-merger fee waiver (if any) of 38 of the surviving funds. Lastly, we collected data from Lipper Analytical on distribution channels used by 244 retail funds in 1995 along with a breakdown of gross expense ratios into waivers and advisory, non-advisory, and $12 \mathrm{~b} 1$ fees.

\section{Self-Selection by Mutual Fund Investors}

\section{$2.1 \quad$ Equity Funds}

The largest part of the finance literature on mutual funds concerns the measurement and prediction of performance. Some of the recent studies demonstrate modest performance persistence among equity funds. For example, both Carhart (1997) and Brown and Goetzmann (1995) show that expected future performance increases in past performance, and that this persistence is especially strong for the worst past performers.

The predictability begs the question as to how investors' allocations across funds respond to past returns. This has been the subject of several studies, including Ippolito (1992), Goetzmann and Peles (1996), Chevalier and Ellison (1997) and Sirri and Tufano (1998), all of which show allocations increasing with past returns, particularly in the region of better past returns. Gruber (1996) and Zheng (1999) find that the net flows earn above-market returns, and propose that some investors are more active or sophisticated than others, benefiting from chasing persistence while the less active or sophisticated stay put and earn below the market. 
The existence and significance of inactive investors is especially apparent with the worst performers. The canonical example is the Steadman family of funds, which performed well and attracted many investors in the 1960s but which later placed consistently last or near last in performance rankings while losing many but not all investors (see Brandstrader (1992)). The remaining investors could in principle have expected improved management performance, but with fees exceeding $20 \%$ per year, ${ }^{1}$ the underperformance was all but guaranteed.

The Steadman combination of higher fees and worse prospects is not an isolated case. Carhart (1997) shows that funds with past performance in the lowest two deciles have not only worse average future performance gross of fees than the other deciles, but also higher fees. Whatever the reason for the higher fees, the remaining investors have distinguished themselves from the population in general, and the funds' original investors in particular, as relatively more willing to pay high prices for bad prospects.

\subsection{Analogous Results for Money Funds}

The interaction between fees, assets and prospects is richer among money funds since the cross section of fees is, to a close approximation, the cross section of underperformance. Figure 1 is a histogram of the fees charged by money funds ${ }^{2}$ in their 1996 fiscal years, showing most fees between 40 and 100 bp, but also a fat tail ranging up to $200 \mathrm{bp}$ and two funds charging nothing. Market commentators (e.g. Malkiel (1996), Bogle (1994), Fredman and Wiles (1998)) often mention that this dispersion in fees is the major source of dispersion in performance. Domian and Reichenstein (1998) tests this proposition and find that fees (plus a dummy variable indicating government-only funds) explain $84 \%$ of the variation in performance. 
[Figure 1]

For our sample, if we plot the 1996 net performance $P$ of the funds in Figure 1 (i.e. net return ${ }^{3}$ in 1996 minus the value-weighted average total return of all other money funds over the same months) against the net fee $f$, we get Figure 2, which shows an extremely close relation. Regressing net performance on fees, we get (t-statistics in parentheses):
$P_{i} \quad=\quad 0.610$
(44.9)
$-1.031 f_{i}$
$(-60.4)$
$\mathrm{R}^{2}=94 \%$
$\mathrm{~N}($ obs $)=224$

The slope of -1 and the $\mathrm{R}^{2}$ of 94 percent confirm that the funds all generate approximately the same gross return (standard deviation is 10bp) then deliver different net returns to investors by charging different fees (standard deviation is 35bp). Money funds are commodity-like in the similarity of their gross returns, but they charge significantly different prices. It follows that the persistence of money fund net performance reflects whatever persistence there is in fees.

[Figure 2]

We can gauge the actual persistence in money fund performance by comparing adjacent years. For each money fund in each year from 1989 to 1995 , we calculate net performance (net return less the value-weighted index) in that year and also in the next. Figure 3 plots the latter against the former, showing persistence far stronger than that of equity funds. For example, Brown and Goetzmann (1995) find that 993 of 2,401 "winner" years of equity funds were followed by "loser" years, whereas in Figure 3, only 87 of 615 winner years precede loser years. Because fees tend to persist, performance persists too.

[Figure 3] 
Do investors impute this persistence into their allocations, the way they appear to with equity funds? With the weekly data we can examine this issue at a high resolution. Every other week, we calculate for each fund the current net returns and fund flows over the next two weeks where ${ }_{F L O W_{t+1}}=\frac{\text { Asset }_{t+1}-\text { Asset }_{t}^{*} *\left(1+\text { NetReturn }_{t+1}\right)}{\text { Asset }_{t}} \cdot{ }^{4}$ We sort into performance bins, and report the bin medians as Figure 4.

[Figure 4]

The relation takes the convex form already detected in equity funds. Flows are positive and sensitive to past performance in the region of good past performance, and negative but relatively insensitive in the region of bad past performance. It is worth noting that this asymmetry is unrelated to the capital-gains tax; there are no capital gains, realized or unrealized, with money funds.

Figures 2 through 4 illustrate some of the rich strategic environment of a money fund's pricing decision. A very low fee would presumably generate operating losses but it almost guarantees very high performance that induces inflow, especially from active investors. Higher fees increase current profits but they almost guarantee lower performance that induces outflow by active investors, to the extent that the fund still has active investors. So the pricing decision simultaneously affects current and future profits, net inflow, and the performance-sensitivity of shareholders.

[Figure 5]

The operating history of the Dreyfus Worldwide Dollar Fund (DWDF) is perhaps the largest-scale example of this interaction. Figure 5 shows the fees charged (left axis, by fiscal year) and assets managed (right axis, weekly) by this fund over the sample period. This fund charged very little in its first two years, during which time its yield 
regularly ranked at or near the top of all money funds, and its assets grew to $\$ 10$ billion. Over time it raised its price, and assets fell to $\$ 2$ billion. The low early fees were interpreted at the time as a "loss leader" strategy, the putative goal being to "lure investors into the fund family with an above-average yield in the hope that they can be

sold other products later." Indeed, a Dreyfus executive called the fund a success because “75 percent of the customers attracted were new to Dreyfus, and 50 percent had never before invested in a mutual fund."6

But whatever its motive, the pricing strategy had a potentially important effect on the price-sensitivity of current shareholders. After two years of low fees, shareholders were a price-sensitive group that left quickly when the fund charged 23 and then $47 \mathrm{bp}$, both below-average prices. After several years of much higher fees, the remaining assets stabilized at $20 \%$ of their former level. Just as there are non-price reasons to leave a mortgage pool (e.g. moving to a new job), there are non-performance reasons for leaving a mutual fund (e.g. buying a house) but the selection for performance-insensitivity among the $20 \%$ remaining was, intuitively, intense and economically significant.

From its investors' point of view, a fund's fee is simply a direct reduction of performance, so performance-insensitivity implies price-insensitivity which, holding all else constant, implies a higher optimal price. Other things equal, a fund should charge relatively more if its current investors are relatively less price-sensitive. The rest of the paper explores the significance of this dynamic to management pricing.

\section{Self-Selection and the Cross Section of Fees}

Do fund flows imply self-selection that is important to pricing? We can not observe everything that a fund's management company learns about its investors, but we 
can observe the week-to-week fluctuation of its assets. If greater outflows correspond to more self-selection for price insensitivity, then a fund that has experienced greater outflow should charge more. This is not the only potential source of cross sectional demand-curve variation, but it is one that is straightforward to measure accurately. We test for the relation first in the panel of retail funds, and then for contrast in a panel of institutional funds. Another potential source of demand-curve variation is the tendency, documented by Capon, Fitzsimons and Prince (1996) and Alexander, Jones and Nigro (1998), for investors with different levels of investing sophistication and knowledge to invest through different distribution channels. Specifically, the more informed and sophisticated invest directly, rather than through brokers. We analyze the cross sectional relation between fee elements and distribution channels, testing whether directlydistributed funds price as if their investors are more price-sensitive.

\subsection{Cross sectional relation between fees and past attrition}

The empirical question is whether the fee dispersion in Figures 1 and 2 is explained by dispersion in previous net fund flows. For each fund $i$ with fiscal-year 1996 fee $f_{i}$ (in annual percent) we calculate $\mathrm{Q}_{i}$, its total net assets in the last week of fiscal-year 1995 , and $\mathrm{MAX}_{i}$, the maximum total net assets reported for $i$ over all weeks up to the last of fiscal-year 1995. So $\mathrm{Q}_{i} / \mathrm{MAX}_{i}$ is $i$ 's asset retention, and $1-\mathrm{Q}_{i} / \mathrm{MAX}_{i}$ is $i$ 's attrition, as of the end of fiscal-year 1995. If the price-sensitivity of a fund's current investors decreases as its attrition increases, and if this consideration is important to pricing, we should find that $f_{i}$ goes up as attrition goes up, i.e. $\mathrm{Q}_{i} / \mathrm{MAX}_{i}$ goes down. Previous research (e.g. Cook and Duffield (1979), Baumol et al. (1990)) has shown money funds' 
asset size to be important to their pricing, so we include $\mathrm{Q}_{i}$ as a separate explanatory variable in this analysis.

We run four cross sectional regressions on the retail fund panel, which has 200 usable observations. The dependent variable is always $f$, and the independent variables are first just $\mathrm{Q} / \mathrm{MAX}$ by itself, then $\mathrm{Q} / \mathrm{MAX}$ and $\mathrm{Q}$, then $\mathrm{Q} / \mathrm{MAX}$ and $\mathrm{Q}$ and $\mathrm{Q}^{2}$, to allow asset size to enter non-linearly, and finally asset size by itself. The prediction is that Q/MAX enters negatively. Results are in Panel A of Table 1.

[Table 1]

The null hypothesis of a non-negative influence of Q/MAX is rejected by all specifications. The coefficient is not only consistently significant but also quite stable as we allow asset size to enter in different ways. The coefficient estimate of -0.2 corresponds to a $10 \mathrm{bp}$ higher fee after $50 \%$ attrition, controlling for the asset shrinkage caused by the attrition, which has its own separate effect on the fee. In unreported results, we find that Q/MAX enters significantly in the subset of funds without breakpoints in their fee schedules, indicating that breakpoints do not drive the results, and we also find that the effect of Q/MAX across non-waiving funds is almost identical to its effect across waiving funds. ${ }^{7}$ Since waiving funds are by construction not charging their contractual limits, this indicates that contract limits are not driving the result either.

The attrition intuition applies much less to the shareholders of institutional funds, so it is worth repeating the four regressions on the institutional fund panel, which has 97 usable observations. In this panel, we would not expect attrition to influence future pricing, so the prediction is that $\mathrm{Q} / \mathrm{MAX}$ does not enter. Results are in Panel B of Table 1. 
The institutional-fund results are a strong contrast to the retail-fund results. The coefficient on $\mathrm{Q} / \mathrm{MAX}$ is never negative. It is insignificantly positive when size is not included, and it is significantly positive when size is included, which is interesting. For our purposes the important point is that the relation between attrition and future pricing is not only robust to size considerations but also specific to funds with consumers as shareholders.

The attrition/future price relation of retail funds, and its contrast to the relation among institutional funds, is presented graphically as Figure 6. Asset retention increases, so attrition decreases, from left to right on the $x$-axis. The fiscal-year 1996 net expense ratio is on the $y$-axis, in annual percent. Funds are sorted into five $\mathrm{Q} / \mathrm{MAX}$ bins, $(0,0.2]$ through $(0.8,1]$, and the bin averages are shown. Retail fees are generally much higher, but they decline as the fund's assets at the fiscal-year-beginning approach their historical maximum.

[Figure 6]

\subsection{Cross sectional relation between fees and distribution channels}

The attrition results support the view that self-selection influences pricing and that demand differs across retail money funds. Still, we cannot rule out a passive scenario where some funds simply charge more than others year after year without regard to selfselection, experiencing attrition along the way. We can't be sure if fees drive the fund flows or vice versa. One way around this chicken-and-egg problem is to relate fees instead to distribution channels, since they are not effects of past fees and since surveys show significant systematic differences of investor types, especially as relate to price sensitivity, across distribution channels. 
Capon, Fitzsimons, and Prince (1996) and Alexander, Jones, and Nigro (1998) summarize survey responses of mutual fund investors and argue that investors who arrive through the direct channel appear more price-sensitive than those brought in by a sales force. Funds pricing off the less price-sensitive demand curves should charge more. We can test this proposition with Lipper data on the distribution channels and fee elements, as of 1995, of 244 retail money funds. The distribution channels are "Direct Primary," "Direct Secondary," "Dealer," "Broker/Dealer," "Wirehouse," "Captive," "Retail Banking," "Insurance," "Affinity," and "Employee." The first two categories constitute the Direct group, the next four constitute the Broker group, and the last four do not group. For fund $i$ we have its end-of-fiscal-year 1995 total net assets, $Q_{i}$, its expense ratio gross of fee waivers, $G R O S S_{i}$, and net of waivers, $N E T_{i}$, and the implied waiver $W A I V E_{i}$, and the three elements of $N E T_{i}$ : Advisory Fee $\left(A D V_{i}\right)$, Non-Advisory Fee $\left(N A D V_{i}\right)$ and $12 \mathrm{~b}-1\left(12 B 1_{i}\right)$. The empirical question is how the fee and the fee elements vary across the distribution-channel types, and in particular, whether the investors who arrive via brokers are charged more.

We run six regressions in which the dependent variable is a fee component, and the independent variables are indicators for distribution-channel types and the log of asset size. For each regression we include an F-test for the null hypothesis that the Broker and Direct funds have the same mean. Results are in Table 2.

[Table 2]

We see that the gross expense ratios of Broker and Direct funds are about the same on average; their difference is small and statistically insignificant. However, their waivers, and therefore their net expense ratios, are significantly different by about $20 \mathrm{bp}$, 
around a third of Direct funds' net fees. So Dealer funds are cheaper because their

sponsors find it preferable, rather than contractually necessary, to charge less. ${ }^{8}$ Among the other components we find higher 12b-1 fees for Broker funds, as would be expected considering that brokers are generally compensated out of $12 \mathrm{~b}-1$ fees, and we also find higher advisory, but not non-advisory, fees. Since it is hard to imagine why brokerintermediated funds would be more expensive to advise, this difference is more evidence that their higher fees are chosen strategically, to maximize profits off their less pricesensitive investors.

Another way to sort out this chicken-and-egg problem is to look instead at fee changes around fund mergers. A fund merger is an exogenous shock to the demand curve of the surviving fund, so we can observe the significance of demand-curve variation to pricing by first measuring the shock and then comparing our measurement to the price change, from before the merger to after, of the surviving fund. By comparing the surviving fund to itself at a different time, we isolate the demand-curve effect by reducing variation in for fund-specific pricing considerations, such as the perceived quality of its services. The next section develops a simple model of re-pricing due to mergers and tests it on the merger sample.

\section{Price Changes around Mergers}

The goal of this section is to establish the significance of demand-curve variation to price variation with an analysis of re-pricing after mergers. For each merger in the sample period we estimate the change in the surviving fund's demand curve, and from that we predict the change in the surviving fund's price. The cross section of realized price changes is compared to the cross section of predictions. To this end we solve a 
simple model which infers the surviving and disappearing funds' pre-merger demand curves and combines them to predict the optimal price revision.

The demand-curve variation that is relevant to pricing may result from the seasoning dynamic of the previous section, or instead from some other differences in the funds' circumstances. Since a fund has comparatively better access to consumers already invested in the other financial products within its complex, one potentially important difference in funds' circumstances is the variety and operating histories of these other products. Similarly, a load complex (e.g. Fidelity, Putnam) would attract investors with different plans, tastes and beliefs than would a no-load complex (e.g. Vanguard, Scudder) and these attributes could correlate with price-sensitivity. There are many other potential circumstances that could determine the type of consumer in closer reach of a fund complex, such as the demographics of the communities where bank branches sell its product (e.g. the communities with Mellon PSFS branches pitching Dreyfus), or of the personnel of firms including the complex on pension-plan menus. The empirical question we address with our model is whether demand-curve variation from all sources is important to pricing. We also test directly for the seasoning dynamic, though without imposing any structure with a formal model.

Before we start testing, it is worth noting that we are not analyzing why funds merge, and that in fact if price-sensitivity were the only consideration in managementpricing, funds would not degrade their price-discrimination by merging. The presumption is that some unmodeled efficiency gain motivates the merger with a benefit exceeding the discrimination-related cost. It is potentially important that money-fund mergers generally result from financial institution mergers (see the Appendix), and an 
institution can reduce the mismatch between merger-partners' shareholders to the extent it has a variety of partners to choose from. Nations Funds, for example, has 65 money funds of all types, including 7 in the Tier 1/Tier 2 retail category, whereas Legg Mason lists 3 total, with only 1 in the Tier 1/Tier 2 retail category, ${ }^{9}$ suggesting that Nations can merge shareholders with relatively more similar shareholders than can Legg Mason.

[Figure 7]

We can get some sense of the shareholders' pre-merger similarity by comparing the fees they were paying. Let $m$ index the 47 mergers, and for each merger let fund 1 be the surviving fund (as identified by MFR), and fund 2 be the disappearing fund, so that (abusing our previous notation slightly) $f_{1, m}$ and $f_{2, m}$ are the pre-merger fees of the surviving and disappearing funds, respectively, and $f_{12, m}$ is the post-merger fee. Figure 7 plots $f_{l, m}$ on $f_{2, m}$, showing a generally positive relation. Its statistical significance is apparent in a simple regression (t-statistics in parentheses):
$f_{1, m} \quad=0.470$
$+\varepsilon_{m}$ $\mathrm{R}^{2}=10.3 \%$ $\mathrm{N}(\mathrm{obs})=45$

The residual mismatch between the funds' shareholders is the focus of the analysis. A description and motivation of the estimated fees is next, followed by the empirical tests.

\subsection{Pricing Model}

The model assumes that a fund chooses its fee $f_{k, m}, k \in\{1,2,12\}$, to maximize its current profits given its current investors' price-sensitivity, which is assumed linear. The marginal cost of managing an extra dollar is fixed at $c$, so the managers' programs are simply to maximize total revenue $\left(f_{k, m}-c\right) * Q_{k, m}$, where $Q_{k, m}$ is assets under management. Downward-sloping demand curves drive the maximizations; before the merger, each fund faces the demand curve 


$$
Q_{k, m}\left(f_{k, m}\right)=a_{k, m}-\left(b_{k, m} / 2\right) f_{k, m}
$$

where $a_{k, m}$ and $b_{k, m}$ are positive numbers. Some familiar math shows the optimal fee and assets for fund $k$ to be $f_{k, m}^{*}=a_{k, m} / b_{k, m}+c / 2$ and $Q_{k, m}^{*}=a_{k, m} / 2-b_{k, m} c / 4$, so our estimate of fund $k$ 's demand curve before the merger, given our observations of optimal fees, $f_{k, m}^{*}$, and optimal asset size, $Q_{k, m}^{*}$, is

$$
Q_{k, m}=\frac{2 Q_{k, m}^{*}}{f_{k, m}^{*}-c}\left(f_{k, m}^{*}-\frac{c}{2}\right)-\frac{Q_{k, m}^{*}}{f_{k, m}^{*}-c} f_{k, m}
$$

The merger combines the demand curves of the funds, so the resulting demand curve relating the post-merger price $f_{12, m}$ and quantity $Q_{12, m}$ of the merged surviving fund is

$$
Q_{12, m}=\frac{2 Q_{1, m}^{*}}{f_{1, m}^{*}-c}\left(f_{1, m}^{*}-\frac{c}{2}\right)+\frac{2 Q_{2, m}^{*}}{f_{2, m}^{*}-c}\left(f_{2, m}^{*}-\frac{c}{2}\right)-\left(\frac{Q_{1, m}^{*}}{f_{1, m}^{*}-c}+\frac{Q_{2, m}^{*}}{f_{2, m}^{*}-c}\right) f_{12, m}
$$

implying the optimal fee

$$
f^{*}{ }_{12, m}=\frac{\left\{\frac{2 Q_{1, m}^{*}}{f_{1, m}^{*}-c}\left(f_{1, m}^{*}-\frac{c}{2}\right)+\frac{2 Q_{2, m}^{*}}{f_{2, m}^{*}-c}\left(f_{2, m}^{*}-\frac{c}{2}\right)\right\}}{\left(\frac{2 Q_{1, m}^{*}}{f_{1, m}^{*}-c}+\frac{2 Q_{2, m}^{*}}{f_{2, m}^{*}-c}\right)}+\frac{c}{2}
$$

A little algebra shows

$$
f^{*}{ }_{12, m}-f^{*}{ }_{1, m}=\left[\left(Q_{2, m}^{*}\left(f_{1, m}^{*}-c\right)\right) /\left(Q_{1, m}^{*}\left(f_{2, m}^{*}-c\right)+Q_{2, m}^{*}\left(f_{1, m}^{*}-c\right)\right]\left(f^{*}{ }_{2, m}-f^{*}{ }_{1, m}\right)\right.
$$

This is the predicted price revision of the surviving fund as a function of variables we can observe, except for the marginal $\operatorname{cost} c$ which we must estimate. The optimal price revision is in the direction of the disappearing fund's fee, and the magnitude depends on the funds' relative sizes.

\section{Some comments on the modeling choices:}

The linear demand curves keep the model tractable and transparent, and they have the useful feature of being recoverable from observable price and quantity data. One way 
to map this model to the question of relative price sensitivity is to assume that a given investor $j$ has demand curve $q_{j}=a-\left(b_{j} / 2\right) f$. Everybody has the same demand $a$ at zero price, but different price sensitivities. If the average $b_{j}$ of the $n$ investors remaining in a fund's investor base is $b$, then the optimal fee is $(n a) /(n b)+c / 2=a / b+c / 2$, so a higher average price sensitivity corresponds to a lower fee.

Although the model accounts for marginal costs, $c$, these are not directly observable. Because Vanguard is considered to charge close to cost, we used its fee of approximately 32 bp between 1990 to 1995 to proxy for marginal costs. The results are robust to the choice of $c .^{10}$

Our assumption that funds can move prices up or down from one day to the next represents the widespread practice of fee waiving. Christoffersen (2001) shows over $60 \%$ of retail money funds waiving fees in 1995 . These funds can generally start charging more or less on any day, without approval from shareholders. It is worth keeping in mind, though, that the latitude of funds to move all the way to the new profitmaximizing fee may be limited by the merger-related regulation in the Investment Company Act of 1940. Section 15(f) requires that the assignment of an investment advisory contract not impose an "unfair burden" on shareholders (15(f)(1)(B)), and that compensation "other than bona fide ordinary compensation as principal underwriter" in the first two post-assignment years would constitute an unfair burden $(15(\mathrm{f})(2)(\mathrm{B}))$. Empirically, this has not prevented fee increases for either surviving-fund or disappearing-fund shareholders (see the Appendix), but there may be some restraining effect on re-pricing which would arguably make it more difficult for to detect the effect of demand-curve variation on optimal pricing. In any case, we can address concerns 
about the feasibility of fee increases by non-waiving funds by limiting the sample to the mergers where the surviving fund was waiving before the merger.

Modeling the managers as maximizing the current profits of their money funds abstracts from the profits of the family's other funds and the tradeoff between current and future profits, both of which appear important in the Dreyfus case. A usable model of the pricing problem's extensive form may be solvable, but is beyond the scope of this paper and our database. The error terms in the regressions are meant to pick up adjustments in price serving objectives other than current profits.

Finally, it is worth noting that our prediction for the merged fund's fee is similar to an asset-weighted average of the unmerged funds' fees. So if, in place of our analysis, we assumed that 1) funds set fees equal to costs, and 2) the cost of a merged fund equals the sum of the costs of the merging funds, we would make a similar estimate of the merged fund's fee. The cross sectional evidence of higher pricing for less price-sensitive investors supports our view that fees are not mechanically equated to costs. We return to this "asset-weighted cost" perspective below.

\subsection{Empirical Results with the Pricing Model}

We first test the prediction that the surviving fund changes its price in the direction of the disappearing fund's fee. For this purpose, the empirical question is how the sign of $f_{12, m}-f_{1, m}$ compares with the sign of $f_{2, m}-f_{1, m}$. The comparison is summarized by Panel A of Table 3, which sorts mergers into rows by $f_{2, m}-f_{1, m}$, and into columns by $f_{12, m}-f_{1, m}$. The null hypothesis is that rows are independent of columns, and the test statistic is the $\chi^{2}$ with 4 degrees of freedom.

[Table 3] 
The results show the surviving fund's price moving significantly in the predicted direction; when a fund absorbs new investors who had been paying more, it charges more. One way to read the panel is that 14 of the 24 times a fund absorbed shareholders of a higher-priced fund, its own price subsequently increased, and that 11 of the 18 times it absorbed a lower-priced fund, its own price declined. The test of independence is rejected, with a p-value of 0.038 , in favor of a positive relation between $f_{2, m}-f_{1, m}$ and $f_{12, m}-f_{1, m}$

Next we test whether the cross section of predicted price changes explains the cross section of actual price changes. We plug the observed values of $Q_{1, m}, Q_{2, m}, f_{1, m}$ and $f_{2, m}$, and also our estimate $c=32 \mathrm{bp}$ into equation 5 to generate the predicted price changes, and then regress the actual price changes $f_{12, m}-f_{1, m}$ on these predictions. The test statistic is the t-statistic for the coefficient on the predictions. The regression results are in Panel A of Table 4.

[Table 4]

Again the results are significantly in the predicted direction. The cross sectional coefficient on the predicted price change is significantly greater than zero, and also not significantly different from 1, its predicted value. From our demand-curve perspective we can foresee a significant portion of a fund's re-pricing after it merges in another fund's shareholders.

An alternate explanation for the relation between the re-pricing of the surviving fund and the relative price of the target fund is that the merger changes the surviving fund's costs in the direction of the target fund's costs. For example, the target fund's shareholders cost more or less per dollar to service, so that the surviving fund's cost per 
dollar changes. Some additional data gives this alternate model a chance to explain the price changes.

Because a fund has account-specific responsibilities (e.g. postage, accounting) we would expect a fixed cost per account, so that the cost per dollar managed, and consequently the fee, is lower if the average account size is higher. Indeed, this is the standard explanation for the lower fees of institutional funds. By this reasoning, a fund's shareholders are more expensive per dollar if their average account size is lower, so if a fund with a higher average account size merges in these shareholders, its cost per dollar should go up, driving up its fee. At the same time, the surviving fund gains assets, and this should drive down its fee. In cross-sectional regressions of money funds' fees on their assets and average account sizes, Cook and Duffield (1979) and Baumol et al. (1990) find significantly negative coefficients on both. The negative relation between fees and size does not support the asset-weighted cost view described above, since it implies that the total cost of a merged fund should be lower than the costs of the separate funds.

To account for the effects of assets and average account size on price adjustment, we repeat the price-change tests with $f_{12, m}-f_{1, m}$ replaced by $f_{12, m}-f_{12, m}^{e x p}$, where $f^{\text {exp }}{ }_{12, m}$ $f_{1, m}$ is the expected price change conditional on the change in the surviving fund's assets and average account size. To generate this expectation, we first estimate, from the general population of funds indexed by $i$, the dependence of fees, $f_{i}$, on assets, $Q_{i}$, and average account size, $A V G A C C_{i}$ with the cross sectional regression of Cook and Duffield (1979), using their log specification (t-statistics in parentheses): ${ }^{11}$

$$
\begin{aligned}
& \log \left(f_{i}\right)=1.81 \quad-0.0777 \log \left(Q_{i}\right) \quad-0.169 \log \left(A V G A C C_{i}\right)+\varepsilon_{i} \quad \mathrm{R}^{2}=23.1 \% \\
& \text { (3.47) (-2.94) } \\
& (-3.20) \\
& \mathrm{N}(\mathrm{obs})=72
\end{aligned}
$$


We replicate the finding of significant influence, in the predicted direction, of assets and average account size. So the formula for $f_{12, m}^{e x p}$ in terms of $Q_{1, m}$ and $Q_{2, m}$ and of $A V G A C C_{1, m}$ and $A V G A C C_{12, m}$, its pre- and post-merger average account size, is

$$
f^{e x p}{ }_{12, m}=f_{1, m}\left[\left(Q_{1, m}+Q_{2, m}\right) / Q_{1, m}\right]^{-0.0777}\left[A V G A C C_{12, m} / A V G A C C_{1, m}\right]^{-0.169} .
$$

For $A V G A C C_{1, m}$ and $A V G A C C_{12, m}$ we use the average account size over the last six premerger months and the first six post-merger months, respectively. ${ }^{12}$ There are 39 mergers with both fee and average account size data. We calculate $f_{12, m}^{\exp }$ for each and repeat the directional test of Table 3 and the cross sectional regression of Table 4 on $f_{12, m}-f_{12, m}^{e x p}$. Results are in Panel B of Table 3 and Panel A of Table 4, respectively.

The results are quite similar to the unadjusted results. The cross sectional regression coefficient is again significantly greater than zero and not significantly different from one. The p-value on the non-parametric test is only marginally significant, but this could be an artifact of rounding. That is, our fee data is only in whole numbers of basis points but our new baseline $f_{12, m}^{\exp }$ is more precise than that, so for example $f^{\text {exp }} 12$ for the Dreyfus/Laurel fund is $70.38 \mathrm{bp}$, and the reported post-merger fee is $70 \mathrm{bp}$. If Dreyfus/Laurel charged exactly $f_{12}^{e x p}$ it would show up in our test as charging less. To cure this problem we repeat the test with $f_{12, m}^{\exp }$ rounded off to the nearest basis point. The results, in Panel C of Table 3, show that this apples-to-apples comparison restores the statistical significance. So while asset and average account size matter to pricing, and while they do change as a result of mergers, these changes do not account for the explanatory power of our model.

As discussed above, mergers where the acquiring fund waived fees before the merger are the best subjects for our analysis. We can identify the pre-merger waiving 
activity of 35 acquiring funds; 20 were waiving, and 15 were not. In Table 4 , the regressions of Panel A are repeated on the waiving subsample in Panel B, and on the nonwaiving subsample in Panel C. Consistent with the intuition, we find a strong and significant relation between the actual and predicted fee changes in the waiving sample. There is no significant relation in the non-waiving sample, but with only 15 observations this failure to reject is not very informative. We repeat also the non-parametric tests of Table 3 on the subsamples. To conserve space we report only the test statistics, ${ }^{13}$ to the right of the test statistics for the full sample. The results for the waiving funds are close to those for the full sample, significant for the first and third specifications and marginally significant for the second, but non-waiving funds show significance for only the first specification. The strong results for waiving funds support the strategic-pricing perspective, and the weaker results for non-waiving funds suggest that contracting restrictions may constrain fund sponsors from reaching their optimal fees.

There could in principle be meaningful changes in service quality that affect pricing, but we have no way to observe this sort of change so we cannot reject the hypothesis that the observed repricing reflects asset-weighting of the service qualities of the merging funds. ${ }^{14}$ Our tactic of using mergers to compare the surviving fund to its earlier self is meant to serve as a control along this dimension; also this alternate model does not deliver the relation between attrition and fees in Table 1.

\subsection{Estimating Demand from Attrition}

Finally, we can approach the re-pricing problem from the seasoning angle of the previous section. The merging funds' observed fees and assets are informative about their demand curves to the extent they were maximizing current profits. But even if the 
funds were pricing to several objectives, the logic that more attrition means less pricesensitivity among the remaining investors should still hold. So if a fund absorbs investors who remain after more attrition than do its current investors it should, other things equal, raise its price.

To test this hypothesis, we add relative attrition to the above model explaining the price changes with asset and average account size changes. Let $R_{k, m}$ represent $\mathrm{Q}_{k, m} / M A X_{k, m}$, defined as before, of fund $k$ just before the merger, so that $R_{2, m} / R_{1, m}$ estimates the relative asset retention of the two funds: the smaller the ratio, the greater the disappeared fund's attrition was relative to the surviving fund's. The prediction is that $\log \left(R_{2, m} / R_{1, m}\right)$ enters negatively. We get (t-statistics in parentheses):

$$
\begin{aligned}
& \log \left(f_{12, m} / f_{1, m}\right)=-0.124+0.053 \log \left(\left(Q_{1, m}+Q_{2, m}\right) / Q_{1, m}\right) \quad-0.399 \log \left(R_{2, m} / R_{l, m}\right) \\
& (-0.80) \quad(0.20) \quad(-2.95) \\
& -0.154 \log \left(\text { AVGACC }_{12, m} / A V G A C C_{1, m}\right) \quad+\quad \varepsilon_{m} \quad \mathrm{R}^{2}=22.1 \% \\
& \mathrm{~N}(\mathrm{obs})=40
\end{aligned}
$$

The coefficient is significant in the predicted direction with a two-sided p-value of 0.006 . Controlling for the usual cost considerations, funds charge more after absorbing investors more self-selected for price insensitivity than their old investors.

\section{Summary and Conclusion}

The puzzling price dispersion in the commodity-like money fund industry is explained, to some degree, by dispersion in the demand curves funds face. Various dynamics can select biased samples of consumers for the subset of investors that is most important to a fund's pricing; the one we explore in detail is the seasoning induced by a fund's own operating history. A history or distribution channel that selected performance-insensitive investors encourages higher pricing, whether by the same fund 
or by a different fund that absorbs the investors. More generally, demand-curve variation explains price variation that some cost considerations can not explain, as evidenced by the predictive power of a demand-side model of re-pricing after mergers, beyond the expected re-pricing due to changes in asset or account size. Our merger results are open to reinterpretation as evidence for pricing of service quality; the influence of this consideration on money management pricing is an area for future research.

This paper provides some simple examples of the potential and empirical significance of shareholder self-selection. It is not intended to be exhaustive, and indeed there are many directions one could take this line of reasoning. There is the natural extension to other fund types, in particular to the actively-managed equity funds that are the primary focus of the mutual-fund literature. This would introduce, however, a hazard we avoided with money funds. The commodity perspective is inappropriate, not only because funds' realized returns differ substantially, but also because their investors view themselves as buying amounts of expected excess returns. That is, an investor paying a higher fee could believe she is buying sufficiently better prospects, and could be right. Without an accurate measure of the cross section of prospects it is difficult to learn about an investor from her fund choice. Rather than try to measure prospects, one could simply assume that the smart money is the active money, ${ }^{15}$ in which case the investors who remain in a fund of any type after more attrition are the relatively less performancesensitive ones. Our prediction is that a fund merging them in should charge relatively more.

Another extension of our analysis is to the other determinants and implications of self-selection. The characteristics of a fund's investors would presumably reflect the 
marketing that brought them in, and, given the ease of transferring balances, the marketing, performance and pricing of the family's other funds. For example, a star performer brings in money for the whole family (Nanda, Wang and Zheng (2000)), but these new investors are not a random sample, and the funds in families that bring in money this way should price accordingly.

The seasoning logic may also have some relevance to the proliferation of funds. Just as a fund family would prefer not to merge inactive investors with active ones, it may also prefer not to alter a fund's management, marketing or pricing in a way that brings active investors into a fund with only inactive investors remaining. The profitmaximizing strategy may be to leave the old fund alone, with its track record still visible, and start a new fund for the new investors. A fund that has done badly is an embarrassment but also an asset. 


\section{Appendix: List of Mergers}

Fund 1

Princor Cash Mgmt Fund

Shearson Daily Dividend

Shearson Daily Dividend

Shearson Daily Dividend

Shearson Daily Dividend

Franklin MF

Emblem Prime Portfolio

RBB MMP/Bedford Class

Centennial Cash Reserves

Cortland Trust Gen MMF

Dreyfus Worldwide Dollar MMF

Prime Cash Series

T Rowe Price Prime Reserve

Prime Value Cash Inv Fund

Smith Barney Cash Portfolio

T-Rowe Price Prime Reserve

Hanover Cash Mgmt Fund

Nations Prime MMF/Inv A

Ambassador MMF

Ivy MMF

Pacific Horizon Prime Fund

Short Term Income/MMP Cl A

Pioneer Cash Reserves Fund

Prime Cash Series

Dreyfus/Laurel Prime I MMF/ Inv Cl

Smith Barney Cash Port/Cl A

Evergreen MMT/Cl Y

American Capital Reserve Fund

Galaxy MMF/Retail

Evergreen $\mathrm{MM} / \mathrm{Cl} \mathrm{A}$

PaineWebber RMA MF/MMP

PaineWebber RMA MF/MMP

CoreFunds Cash Reserve/Cl C

Vista Global MMF/Vista Shrs

Pegasus MMF

Transamerica Cash Reserve

Transamerica Cash Reserve

Boston Company Cash Mgmt

Woodward MMF

Evergreen MMT/Cl A

Stagecoach MMF/Cl A

Nations Prime Fund/Primary A

1784 Prime MMF

Legg Mason Cash Reserve

Franklin Money Fund

Stepstone MMF

Nations Prime/Inv B
Fund 2

EGT Money Market Trust

Hutton Cash Reserve Mgt.

Hutton AMA Cash Fund

Shearson FMA Cash

Lehman Management Cash Res.

BIRR Wilson Money Fund

Seagate Prime Obligations Fund

Home Cash Reserves

Massmutual Money Market Fund

Parkway Cash Fund

Daiwa Money Fund

So Farm Bureau Cash Fund

Bell Atlantic MMP

Altura Prime Oblig Port

Vantage Cash Money Market Fund

USF\&G Cash Reserve Fund

CBC Cornerstone Prime MMF

Nations MMF/Investor A

St. Clair MMF/Prime Oblig

American Investors Money Fund

First Funds of America MMF

Daily Income Fund

Pioneer Money Market Account

Voyageur Money Market Fund

Dreyfus/Laurel Cash Mgmt/Inv

Smith Barney Shearson Daily Div

First Union MMP/CI Y Shrs

Van Kampen Merritt MMF/Class A

Shawmut Prime MMF/Invmt Shrs

FFB Cash Management Fund

Kidder Peabody Premium Account

Kidder Peabody Cash Reserve

Conestoga Cash Mgmt/Cl A Investor

Hanover Cash Management

Prairie Money Market Fund/Cl A

Transamerica Premium Cash Acct

Transamerica Money Market Fund

American Express MMF

Bison MMF/Money Market Port

First Union MMP/Cl A Invmt Shrs

Pacifica Money Market Fund

Peachtree Prime MMF/Invmt Shrs

BayFunds MMP/Investment Shrs

Bartlett/Cash Reserves Fund

Templeton Money Fund

HighMark Dvsfd Oblig/Cl A

Pilot S-T Divsfd Assets/Admin $\begin{array}{clllll}\text { Date } & \mathbf{Q}_{1} & \mathbf{Q}_{2} & \mathbf{f}_{1} & \mathbf{f}_{2} & \mathbf{f}_{12}\end{array}$ $\begin{array}{llllll}12 / 2 / 88 & 70 & 26 & 1.02 & 1.34 & 1.00\end{array}$

$\begin{array}{llllll}12 / 2 / 88 & 4932 & 2789 & 0.80 & 0.59 & 0.70\end{array}$

$\begin{array}{llllll}12 / 2 / 88 & 4932 & 1735 & 0.80 & 0.60 & 0.70\end{array}$

$\begin{array}{lllllll}12 / 2 / 88 & 4932 & 1942 & 0.80 & 0.66 & 0.70\end{array}$

$\begin{array}{llllll}12 / 2 / 88 & 4932 & 288 & 0.80 & 0.71 & 0.70\end{array}$

$\begin{array}{llllll}12 / 30 / 88 & 1429 & 11 & 0.80 & 1.12 & 0.73\end{array}$

$\begin{array}{llllll}5 / 18 / 90 & 311 & 81 & 0.61 & 0.66 & 0.62\end{array}$

$\begin{array}{llllll}6 / 1 / 90 & 151 & 554 & 0.93 & 0.93 & 0.92\end{array}$

$\begin{array}{llllll}3 / 29 / 91 & 52 & 83 & 1.00 & 1.13 & 1.25\end{array}$

$\begin{array}{llllll}9 / 6 / 91 & 847 & 63 & 1.01 & 1.00 & 1.00\end{array}$

$\begin{array}{llllll}9 / 20 / 91 & 8989 & 9 & 0.01 & 1.10 & 0.47\end{array}$

$\begin{array}{llllll}11 / 15 / 91 & 756 & 23 & 0.94 & 1.24 & 0.99\end{array}$

$\begin{array}{llllll}12 / 27 / 91 & 4229 & 13 & 0.75 & 0.75 & 0.75\end{array}$

$\begin{array}{llllll}1 / 17 / 92 & 1111 & 191 & 0.51 & 0.67 & 0.50\end{array}$

$6 / 26 / 92 \quad 1805 \quad 1120 \quad 0.52 \quad 0.56 \quad 0.64$

$\begin{array}{llllll}8 / 21 / 92 & 3844 & 28 & 0.78 & 0.97 & 0.74\end{array}$

$\begin{array}{llllll}10 / 2 / 92 & 234 & 309 & 0.67 & 0.58 & 0.58\end{array}$

$\begin{array}{llllll}11 / 13 / 92 & 283 & 2 & 0.65 & 0.43 & 0.65\end{array}$

$\begin{array}{llllll}11 / 20 / 92 & 334 & 231 & 0.44 & 0.79 & 0.53\end{array}$

$\begin{array}{llllll}1 / 29 / 93 & 17 & 3 & 0.85 & 0.63 & 0.85\end{array}$

$\begin{array}{llllll}2 / 26 / 93 & 1160 & 111 & 0.56 & 0.55 & 0.52\end{array}$

6/18/93 $791 \quad 340 \quad 0.83 \quad 0.70 \quad 0.91$

$\begin{array}{llllll}7 / 1 / 94 & 63 & 107 & 0.75 & 1.29 & 0.88\end{array}$

$\begin{array}{llllll}10 / 28 / 94 & 834 & 17 & 0.99 & 0.85 & 0.99\end{array}$

$\begin{array}{llllll}11 / 4 / 94 & 123 & 4 & 0.71 & 0.97 & 0.70\end{array}$

$\begin{array}{llllll}11 / 18 / 94 & 3041 & 14658 & 0.64 & 0.70 & 0.62\end{array}$

$\begin{array}{llllll}7 / 7 / 95 & 247 & 56 & 0.32 & 0.41 & 0.45\end{array}$

$\begin{array}{llllll}9 / 22 / 95 & 342 & 20 & 1.00 & 1.08 & 1.02\end{array}$

$\begin{array}{llllll}12 / 1 / 95 & 610 & 271 & 0.74 & 0.71 & 0.71\end{array}$

$\begin{array}{lllllll}1 / 19 / 96 & 864 & 598 & 0.81 & 0.66 & 0.79\end{array}$

$\begin{array}{lllllll}2 / 16 / 96 & 6401 & 516 & 0.59 & 0.70 & 0.59\end{array}$

$\begin{array}{llllll}2 / 16 / 96 & 6401 & 856 & 0.59 & 0.74 & 0.59\end{array}$

$\begin{array}{llllll}4 / 12 / 96 & 19 & 2 & 0.73 & 0.56 & 0.75\end{array}$

$\begin{array}{llllll}5 / 3 / 96 & 117 & 1451 & 0.57 & 0.58 & 0.59\end{array}$

$\begin{array}{llllll}9 / 13 / 96 & 1851 & 402 & 0.75 & 0.51 & 0.74\end{array}$

$\begin{array}{llllll}11 / 30 / 90 & 434 & 127 & 0.45 & 0.45 & 0.57\end{array}$

$\begin{array}{llllll}5 / 31 / 91 & 330 & 16 & 0.46 & 1.30 & 0.63\end{array}$

$\begin{array}{llllll}2 / 7 / 92 & 270 & 41 & 0.86 & \# N / A & 0.97\end{array}$

$\begin{array}{llllll}1 / 1 / 93 & 1118 & 335 & 0.52 & 0.45 & 0.47\end{array}$

$\begin{array}{llllll}7 / 7 / 95 & 3 & 566 & \text { \#N/A } & 0.61 & 0.75\end{array}$

$\begin{array}{llllll}9 / 6 / 96 & 3542 & 182 & 0.75 & 0.64 & 0.75\end{array}$

$\begin{array}{llllll}9 / 27 / 96 & 2467 & 39 & 0.3 & 0.5 & 0.3\end{array}$

$\begin{array}{lllllll}12 / 6 / 96 & 97 & 45 & 0.62 & 0.87 & 0.65\end{array}$

$\begin{array}{llllll}12 / 20 / 96 & 1270 & 39 & 0.75 & 0.78 & 0.78\end{array}$

$\begin{array}{llllll}12 / 31 / 96 & 1237 & 115 & 0.75 & 0.96 & 0.68\end{array}$

$\begin{array}{llllll}4 / 25 / 97 & 529 & 141 & 0.73 & 0.75 & 0.75\end{array}$

$\begin{array}{llllll}5 / 16 / 97 & 358 & 263 & 0.55 & 0.52 & 0.55\end{array}$ 


\section{Endnotes:}

${ }^{1}$ In its fiscal year ended June 30, 1998, the Steadman American Industry Fund had an expense ratio of $22.57 \%$. Of the $1.347 \mathrm{M}$ shares held by investors at the beginning of that fiscal year, 1.138M remained at the end.

${ }^{2}$ Unless otherwise specified, all money funds from this point onward are Tier 1 and Tier 2 retail funds, as defined by MFR.

${ }^{3}$ The annual total return used here is the average of the 7-day yields over the weeks in that year.

${ }^{4}$ This yields 56,981 non-overlapping observations. We take medians, rather than means, because the smallest funds generate some enormous outliers, and some other funds jump abruptly in size due to exogenous events such as mergers. We get a very similar picture if we take means after eliminating asset-increases above $50 \%$.

${ }^{5}$ Petruno (1990). See Nanda, Wang and Zheng (2000) for a discussion of star-based fund marketing.

${ }^{6}$ Laderman (1992) indirectly quoting Dreyfus president and chief operating officer Joseph DiMartino.

${ }^{7}$ Complete results available upon request.

${ }^{8}$ When a Putnam fund failed to attract much inflow with a price cut, one explanation offered was that fee-sensitive investors “probably don't do business with load-fund companies such as Putnam.” Damato (1999).

${ }^{9}$ As reported by IBC/Donoghue at www.ibcdata.com for the week ending July 13, 1999

${ }^{10}$ Previous versions (available on request) of this paper used (implicitly) $c=0 \mathrm{bp}$, and results were similar. 
${ }^{11}$ Funds generally do not report information on average account size or the number of shareholders. The data for this regression are from a 1995 Lipper survey which returned average account size information for 72 funds in the Tier 1/Tier 2 retail category. These are the 72 observations in the regression. It is worth noting that what a fund considers to be one "account" is sometimes a master account with subaccounts. Lipper considers this survey data not to have this problem, i.e. that the individual subaccounts are counted separately.

12 These account-size figures were hand-collected for us by IBC/Donoghue from their archives. They found data on 40 of the 47 surviving funds. Because we could not find the fee of the disappeared fund for Boston Company Cash Management, we used 39 observations in the regression.

${ }^{13}$ Complete results are available upon request.

${ }^{14}$ Using data from Wiesenberger (1990), we relate fees to a fund's menu of services including "telephone exchange privilege," "payroll deduction plan available," "bank draft payment plan," "self-employed retirement plan," "individual retirement plan," "checkwriting privilege," "minimum amount initial purchase," and "minimum amount subsequent purchase." The regressions (available upon request) show only the checkwriting service entering significantly, but it comes in negative, obviously not the cost or benefit of this service. These results indicate that prices are not explained by the menu of services, but they do not address quality.

${ }^{15}$ One should bear in mind what this assumes about internet-fund investors. 


\section{References}

Alexander, Gordon J., Jonathan D. Jones and Peter J. Nigro, 1998, "Mutual fund shareholders: Characteristics, investor knowledge and sources of information," Financial Services Review, 7, 301-316.

Baumol, William J., Stephen M. Goldfeld, Lilli A. Gordon, and Michael F. Koehn, 1990, The Economics of Mutual Fund Markets: Competition versus Regulation, Kluwer Academic Publishers, Boston, MA.

Bogle, John C., 1994, Bogle on mutual funds: new perspectives for the intelligent investor, Irwin, Burr Ridge, IL.

Brandstrader, J.R., 1992, "Better (in the) red than dead," Barron's, October 26, M14-M15.

Brown, Stephen J. and William N. Goetzmann, 1995, "Performance persistence," Journal of Finance, 50, 679-698.

Carhart, Mark M., 1997, "On persistence in mutual fund performance," Journal of Finance, 52, 57-82.

Capon, Noel, Gavin Fitzsimons, and Roger Prince, 1996, "An individual level analysis of the mutual fund investment decision," Journal of Financial Services Research, $10,59-82$.

Chevalier, Judith and Glen Ellison, 1997, "Risk-taking by mutual funds as a response to incentives," Journal of Political Economy, 105, 1167-1200.

Christoffersen, Susan E. K., 2001, "Why do money fund managers voluntarily waive their fees?," Journal of Finance, 56, 1117-1140. 
Cook, Timothy Q., and Jeremy G. Duffield, 1979, "Average costs of money market mutual funds," Federal Reserve Bank of Richmond Economic Review, 65, 32-39.

Damato, Karen, 1999, "How investors failed to note a fund benefit: A cut in fees," Wall Street Journal, April 29.

Domian, Dale L., and William Reichenstein, 1998, "Performance and persistence in money market fund returns," Financial Services Review, 6, 169-183.

Fredman, Albert J. and Russ Wiles, 1998, How Mutual Funds Work, Prentice-Hall, Paramus, NJ.

Goetzmann, William N., and Nadav Peles, 1996, "Cognitive dissonance and mutual fund investors," Journal of Financial Research, 20, 145-158.

Gruber, Martin J., 1996, "Another puzzle: the growth in actively managed mutual funds," Journal of Finance, 51, 783-810.

Ippolito, Richard A., 1992, "Consumer reaction to measures of poor quality: evidence from the mutual fund industry," Journal of Law and Economics, 35, 45-70.

Laderman, Jeffrey M., 1992, "Dreyfus: No longer king of the jungle," Business Week, September 28, 114.

Malkiel, Burton G., 1996, A Random Walk Down Wall Street, W.W. Norton, New York.

Nanda, Vikram, Z. Jay Wang and Lu Zheng, 2001, "Family values and the star phenomenon," Working Paper 01-007, University of Michigan.

Petruno, Tom, 1990, "Rival's Ads are Deceptive: Vanguard Charges," Los Angeles Times, March 22, D2. 
Schwartz, Eduardo S. and Walter N. Torous, 1989, "Prepayment and the valuation of mortgage-backed securities," Journal of Finance 44, 375-392.

Sirri, Erik R. and Peter Tufano, 1998, "Costly search and mutual fund flows," Journal of Finance 53, 1589-1622.

Tufano, Peter, and Matthew Sevick, 1997, "Board structure and fee-setting in the U.S. mutual fund industry," Journal of Financial Economics 46, 321-355.

Wiesenberger Investment Companies Service, 1990, Investment Companies, Warren, Gorham \& Lamont Inc., New York.

Zheng, Lu, 1999, "Is money smart? A study of mutual fund investors' fund selection ability," Journal of Finance 54, 901-933. 
Table 1

\section{Regressions of fees on attrition for retail and institutional funds}

\begin{tabular}{|c|c|c|c|c|c|c|}
\hline \multicolumn{7}{|c|}{ Panel A: Retail Funds } \\
\hline$f_{i}=$ & $\begin{array}{l}0.732 \\
\mathbf{( 4 2 . 0 )}\end{array}$ & $\begin{array}{l}-0.011 Q_{i} \\
(\mathbf{- 2 . 7 8 )}\end{array}$ & & & $+\varepsilon_{i}$ & $\begin{array}{l}\mathrm{R}^{2}=3.0 \% \\
\mathrm{~N}=200\end{array}$ \\
\hline$f_{i}=$ & $\begin{array}{l}0.872 \\
(\mathbf{1 6 . 9 )}\end{array}$ & $\begin{array}{c}-0.009 \mathrm{Q}_{i} \\
(-1.95)\end{array}$ & & $\begin{array}{l}-0.184 \mathrm{Q}_{i} / \mathrm{MAX}_{i} \\
\mathbf{( - 2 . 8 8 )}\end{array}$ & $+\varepsilon_{i}$ & $\begin{array}{l}\mathrm{R}^{2}=6.9 \% \\
\mathrm{~N}=200\end{array}$ \\
\hline$f_{i}=$ & $\begin{array}{l}0.873 \\
(\mathbf{1 7 . 0 )}\end{array}$ & $\begin{array}{l}-0.020 \mathrm{Q}_{i} \\
(-1.69)\end{array}$ & $\begin{array}{l}-0.001\left(\mathrm{Q}_{i}\right)^{2} \\
(0.98)\end{array}$ & $\begin{array}{l}-0.175 \mathrm{Q}_{i} / \mathrm{MAX}_{i} \\
\mathbf{( - 2 . 7 2 )}\end{array}$ & $+\varepsilon_{i}$ & $\begin{array}{l}\mathrm{R}^{2}=7.4 \% \\
\mathrm{~N}=200\end{array}$ \\
\hline$f_{i}=$ & $\begin{array}{c}0.877 \\
\mathbf{( 1 6 . 9 )}\end{array}$ & & & $\begin{array}{l}-0.206 \mathrm{Q}_{i} / \mathrm{MAX}_{i} \\
\mathbf{( - 3 . 2 7 )}\end{array}$ & $+\varepsilon_{i}$ & $\begin{array}{l}\mathrm{R}^{2}=5.1 \% \\
\mathrm{~N}=200\end{array}$ \\
\hline \multicolumn{7}{|c|}{ Panel B: Institutional Funds } \\
\hline$\overline{f_{i}}=$ & $\begin{array}{l}0.439 \\
\text { (21.1) }\end{array}$ & $\begin{array}{l}-0.057 \mathrm{Q}_{i} \\
\mathbf{( - 4 . 0 5 )}\end{array}$ & & & $+\varepsilon_{i}$ & $\begin{array}{l}R^{2}=14.7 \% \\
N=97\end{array}$ \\
\hline$f_{i}=$ & $\begin{array}{l}0.364 \\
(\mathbf{8 . 6 4})\end{array}$ & $\begin{array}{l}-0.064 \mathrm{Q}_{i} \\
\mathbf{( - 4 . 5 0 )}\end{array}$ & & $\begin{array}{l}+0.121 \mathrm{Q}_{i} / \mathrm{MAX}_{i} \\
(\mathbf{2 . 0 3})\end{array}$ & $+\varepsilon_{i}$ & $\begin{array}{l}\mathrm{R}^{2}=18.3 \% \\
\mathrm{~N}=97\end{array}$ \\
\hline$f_{i}=$ & $\begin{array}{l}0.387 \\
(\mathbf{9 . 0 3})\end{array}$ & $\begin{array}{l}-0.136 \mathrm{Q}_{i} \\
\mathbf{( - 3 . 6 6 )}\end{array}$ & $\begin{array}{l}+0.015\left(\mathrm{Q}_{i}\right)^{2} \\
(\mathbf{2 . 0 9 )}\end{array}$ & $\begin{array}{l}+0.133 \mathrm{Q}_{i} / \mathrm{MAX}_{i} \\
(\mathbf{2 . 2 6})\end{array}$ & $+\varepsilon_{i}$ & $\begin{array}{l}\mathrm{R}^{2}=22.0 \% \\
\mathrm{~N}=97\end{array}$ \\
\hline$f_{i}=$ & $\begin{array}{l}0.353 \\
(1.66)\end{array}$ & & & $\begin{array}{l}+0.053 \mathrm{Q}_{i} / \mathrm{MAX}_{i} \\
(0.83)\end{array}$ & $+\varepsilon_{i}$ & $\begin{array}{l}\mathrm{R}^{2}=0.7 \% \\
\mathrm{~N}=97\end{array}$ \\
\hline
\end{tabular}

The net fee of fund $i, f_{i}$, is measured in percent of net assets in the 1996 fiscal year from Lipper Analytical Services. Q is the net asset size of the fund in the last week of 1995 measured in billions of dollars from IBC Donoghue. Asset retention (Q/MAX) is measured as the net asset value of the fund in the last week of 1995 divided by the maximum size it attained in its history between November 1987 and the last week of 1995 from IBC Donoghue. Attrition is measured as one minus asset retention $(1-\mathrm{Q} / \mathrm{MAX})$. $\mathrm{t}$-statistics are provided in brackets with bold indicating signficant difference from zero at the five percent level. 
Table 2

\section{Cross Sectional Relation between Fees and Distribution Methods In Annual Percent}

\begin{tabular}{lcccccc}
\hline & Gross & Net & Waive & Adv & Nadv & $12 B 1$ \\
\hline Direct & 1.604 & 0.929 & 0.674 & -0.074 & 0.723 & 0.283 \\
Broker & 1.578 & 1.131 & 0.447 & 0.022 & 0.688 & 0.423 \\
Bank & 1.339 & 0.939 & 0.401 & 0.067 & 0.504 & 0.369 \\
Insurance & 1.684 & 1.161 & 0.522 & 0.030 & 0.778 & 0.352 \\
Affinity & 1.525 & 1.119 & 0.406 & 0.098 & 0.775 & 0.248 \\
Employee & 0.843 & 0.549 & 0.294 & -0.216 & 0.559 & 0.207 \\
log(Q) & -0.115 & -0.053 & -0.062 & 0.046 & -0.052 & -0.044 \\
& & & & & & \\
\hline Direct=Broker & 0.12 & 13.21 & 9.90 & 2.82 & 0.40 & 12.07 \\
p-value & 0.733 & $<0.001$ & 0.002 & 0.094 & 0.529 & $<0.001$ \\
& & & & & &
\end{tabular}

These regressions use fiscal-year 1995 data from Lipper. Fund $i$ 's gross expense ratio is $G R O S S_{i}$ and its fee waiver is $W A I V E_{i}$, so its net expense ratio $N E T_{i}$ is $G R O S S_{I}-W A I V E_{i}$. The net expense ratio has three components: the advisory fee $A D V_{i}$, the non-advisory fee $N A D V_{i}$, and the $12 \mathrm{~b}-1$ fee $12 B 1_{i}$. Using Lipper's definitions, Direct $t_{i}$ is 1 if fund $i$ is "Primary Direct" or "Secondary Direct," Broker is 1 if fund $i$ is "Dealer," "Broker/Dealer," "Wirehouse" or "Captive," Bank, Insurance, Affinity and Employee are 1 if fund $i$ is "Retail Banking," "Insurance," "Affinity," or "Employee," respectively. All are 0 otherwise. Fund $i$ 's total net assets at the end of its 1995 fiscal year is $Q_{i}$. Each fee component is regressed on the indicator variables and $\log (\mathrm{Q})$. At the bottom of each column is an F-test, and the associated p-value, for the null hypothesis that the coefficients on Direct and Broker are the same. The number of observations in each regression is 244 . In our sample, the break-down by direct, broker, bank, insurance, affinity, and employee distribution channel is 47 , $96,73,23,4$, and 1 , respectively. 
Table 3

Non-parametric tests of fee changes following mergers

\begin{tabular}{|c|c|c|c|c|c|c|}
\hline Panel A: & Fees, unadjusted & & & & & \\
\hline & & & $12-f_{1}:$ & & & \\
\hline$f_{2}-f_{1}$ & $\leq 0$ & & $=0$ & $>0$ & & \\
\hline$<0$ & 11 & & 5 & 2 & & \\
\hline$=0$ & 1 & & 1 & 1 & & \\
\hline$>0$ & 7 & & 3 & 14 & & \\
\hline Pearson C & quared Test (4): & 10.12 & Waiving & 10.53 & Non-Waiving & 12.05 \\
\hline $\operatorname{Prob}\left(\chi^{2}>\lambda\right.$ & & 0.038 & & 0.032 & 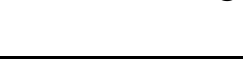 & 0.017 \\
\hline Panel B: & $\begin{array}{l}\text { Fees adjusted for } \\
\text { to the nearest bas }\end{array}$ & $\begin{array}{l}\text { sts and } \\
\text { point. }\end{array}$ & average a & int bala & nce with no ro & bunding \\
\hline & & $-f^{x p p}$ & & & & \\
\hline$f_{2}-f_{1}$ & $\leq 0$ & & $>0$ & & & \\
\hline$<0$ & 11 & & 6 & & & \\
\hline$=0$ & 2 & & 1 & & & \\
\hline$>0$ & 5 & & 14 & & & \\
\hline $\begin{array}{l}\text { Pearson C } \\
\operatorname{Prob}\left(\chi^{2}>x\right.\end{array}$ & $\begin{array}{l}\text { quared Test (2): } \\
\text { 5)) }\end{array}$ & $\begin{array}{l}5.87 \\
0.053\end{array}$ & Waiving & $\begin{array}{l}5.91 \\
0.052\end{array}$ & Non-Waiving & $\begin{array}{l}3.31 \\
0.191\end{array}$ \\
\hline
\end{tabular}

Panel C: Fees adjusted for costs and average account balance with rounding. $f_{12-} f^{\text {exp }}{ }_{12}$ :

$f_{2}-f_{l}$

$<0$

$=0$

$>0$

\begin{tabular}{rll}
$<0$ & $=0$ & $>0$ \\
\hline 11 & 1 & 5 \\
0 & 2 & 1 \\
4 & 5 & 10
\end{tabular}

Pearson Chi-Squared Test (4):

$\operatorname{Prob}\left(\chi^{2}>\chi^{2}(.05)\right)$

12.12 Waiving 0.016

12.41 Non-Waiving $\mathbf{5 . 0 3}$

0.015

0.284

$f_{1}$ and $f_{2}$ are the net fees of the surviving and disappearing fund, respectively, in their last complete fiscal years before the merger. $f_{12, m}$ is the net fee of the surviving fund in the first complete fiscal year after the merger. $f^{e x p}{ }_{12}$ is the expected fee charged by the surviving fund after adjusting for cost factors, asset size and average account balance. Using 1995 survey data from Lipper Analytical, the estimated relation between fees, asset size and account size is $\log \left({ }^{x p}{ }_{12} / f_{1}\right)=-0.077 * \log \left(Q_{12} / Q_{1}\right)-0.169 * \log \left(\operatorname{Avg} A c c t_{12} / \operatorname{Avg} A c c t_{1}\right)$. Actual asset size, Q, and average account balances, AvgAcct, around the merger were provided by IBC Donoghue. Panel $B$ does not round $f_{12}-f^{\exp }{ }_{12}$ to the nearest basis point while Panel $C$ rounds $f_{12}-f^{\text {exp }}{ }_{12}$ to the nearest basis point. At the bottom of each panel is a $\chi^{2}$ test statistic, and its associated p-value, for the null hypothesis that rows and columns are independent. We repeat the same test for funds waiving and not waiving fees premerger and report the test statistics. 
Table 4

Regressions of actual on predicted price changes

In Annual Percent

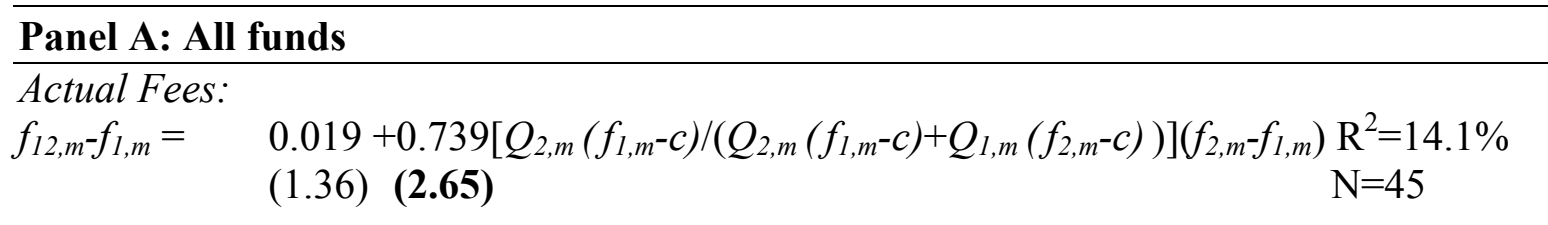

Actual Fees Adjusted for Account $Q$ and Asset $Q$ :

$\begin{aligned} & f_{12, m}-f_{12, m}^{\exp }= 0.028+0.655\left[Q_{2, m}\left(f_{1, m}-c\right) /\left(Q_{2, m}\left(f_{1, m}-c\right)+Q_{1, m}\left(f_{2, m}-c\right)\right)\right]\left(f_{2, m}-f_{1, m}\right) \\ &(1.77)(\mathbf{2 . 1 2}) \\ & \mathrm{R}=10.8 \% \\ & \mathrm{~N}=39\end{aligned}$

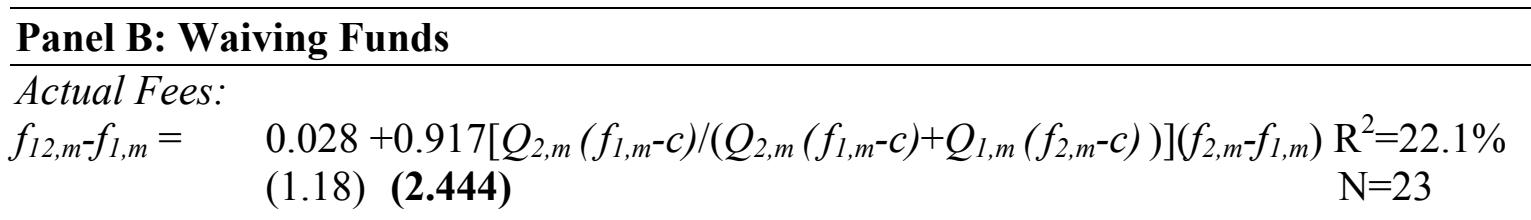

Actual Fees Adjusted for Account $Q$ and Asset Q:

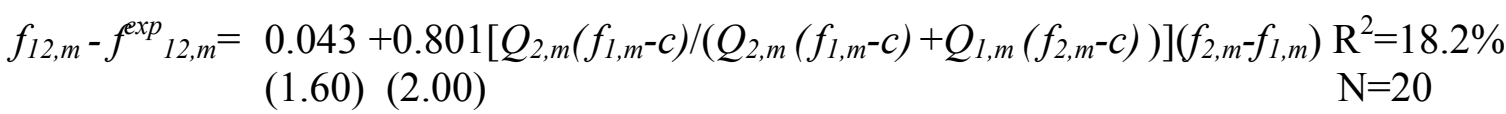

\begin{tabular}{ll}
\hline Panel C: Non-waiving funds & \\
\hline Actual Fees: & \\
$f_{12, m}-f_{l, m}=0.0255-0.466\left[Q_{2, m}\left(f_{l, m}-c\right) /\left(Q_{2, m}\left(f_{1, m}-c\right)+Q_{l, m}\left(f_{2, m}-c\right)\right)\right]\left(f_{2, m}-f_{l, m}\right)$ & $\mathrm{R}^{2}=3.13 \%$ \\
$(1.395) \quad(-0.648)$ & $\mathrm{N}=15$
\end{tabular}

Actual Fees Adjusted for Account $Q$ and Asset $Q$ :

$f_{12, m}-f_{12, m}^{\exp }=0.0269-0.3236\left[Q_{2, m}\left(f_{1, m}-c\right) /\left(Q_{2, m}\left(f_{1, m}-c\right)+Q_{1, m}\left(f_{2, m}-c\right)\right)\right]\left(f_{2, m}-f_{1, m}\right) \mathrm{R}^{2}=1.52 \%$

(1.47) (-0.4487) $\quad \mathrm{N}=15$

$\overline{f_{l, m}}$ and $f_{2, m}$ are the net fees of the surviving and disappearing fund, respectively, in the $m^{\text {th }}$ money fund merger, in their last complete fiscal years before the merger. $f_{12, m}$ is the net fee of the surviving fund in the first complete fiscal year after the merger. $Q_{l, m}$ and $Q_{2, m}$ are the assets under management of the funds before the merger. The second regression includes $f^{\text {exp }}{ }_{12}$ for the expected fee charged by the surviving fund after adjusting for cost factors, asset size and average account balance. Using 1995 survey data from Lipper Analytical, the estimated relation between fees, asset size and account size is $\log \left(f^{\exp }{ }_{12} / f_{1}\right)=$ $0.077 * \log \left(Q_{12} / Q_{1}\right)-0.169 * \log \left(\operatorname{Avg} A c c t_{12} / A v g A c c t_{1}\right)$. Actual asset size, Q, and average account balances, AvgAcct, around the merger were provided by IBC Donoghue. Panels B and C separate the sample into funds that waived and did not waive prior to the merger. $t$-statistics are in parentheses and bold indicates significant difference from zero at the five percent level. 


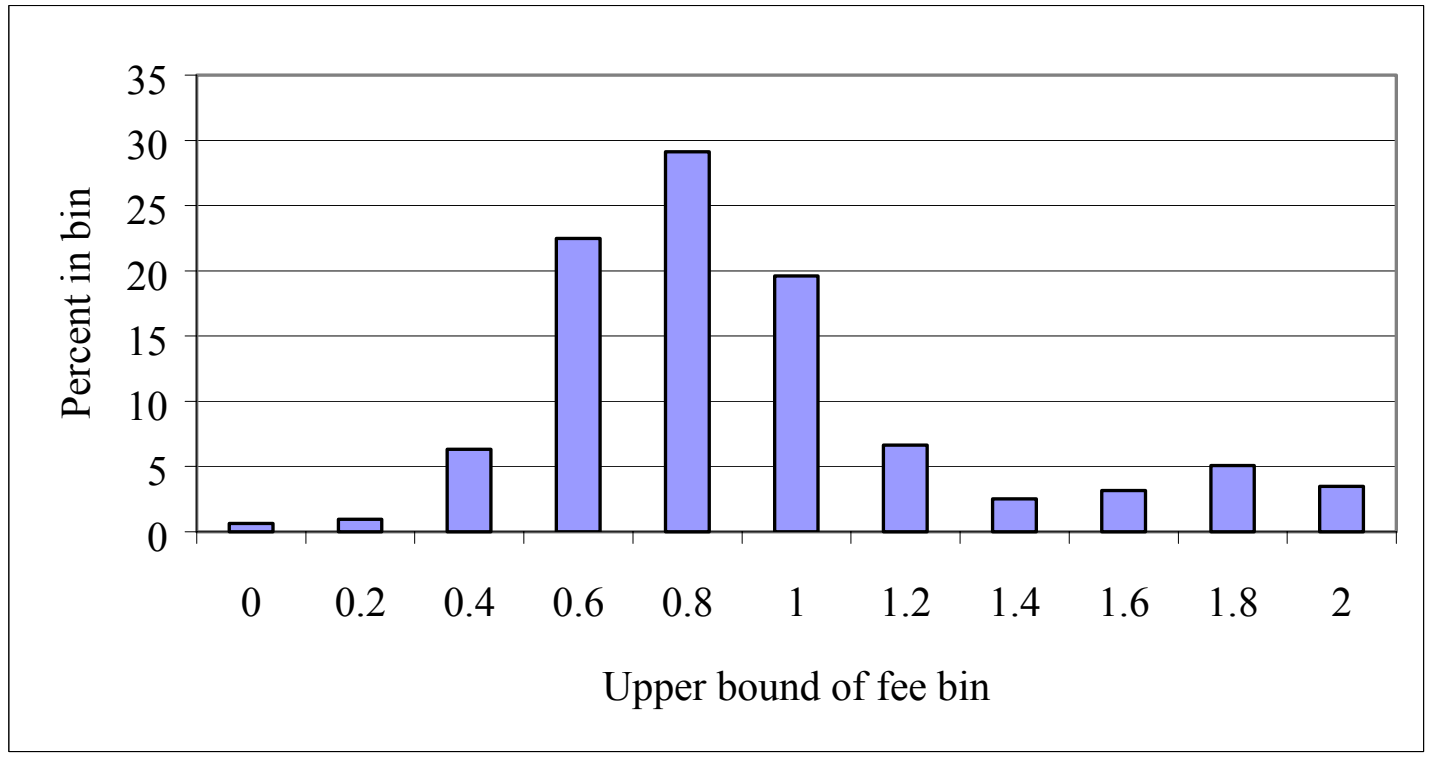

Figure 1. Net fees of Tier 1 and Tier 2 retail money funds charged in FY96, in annual percent.

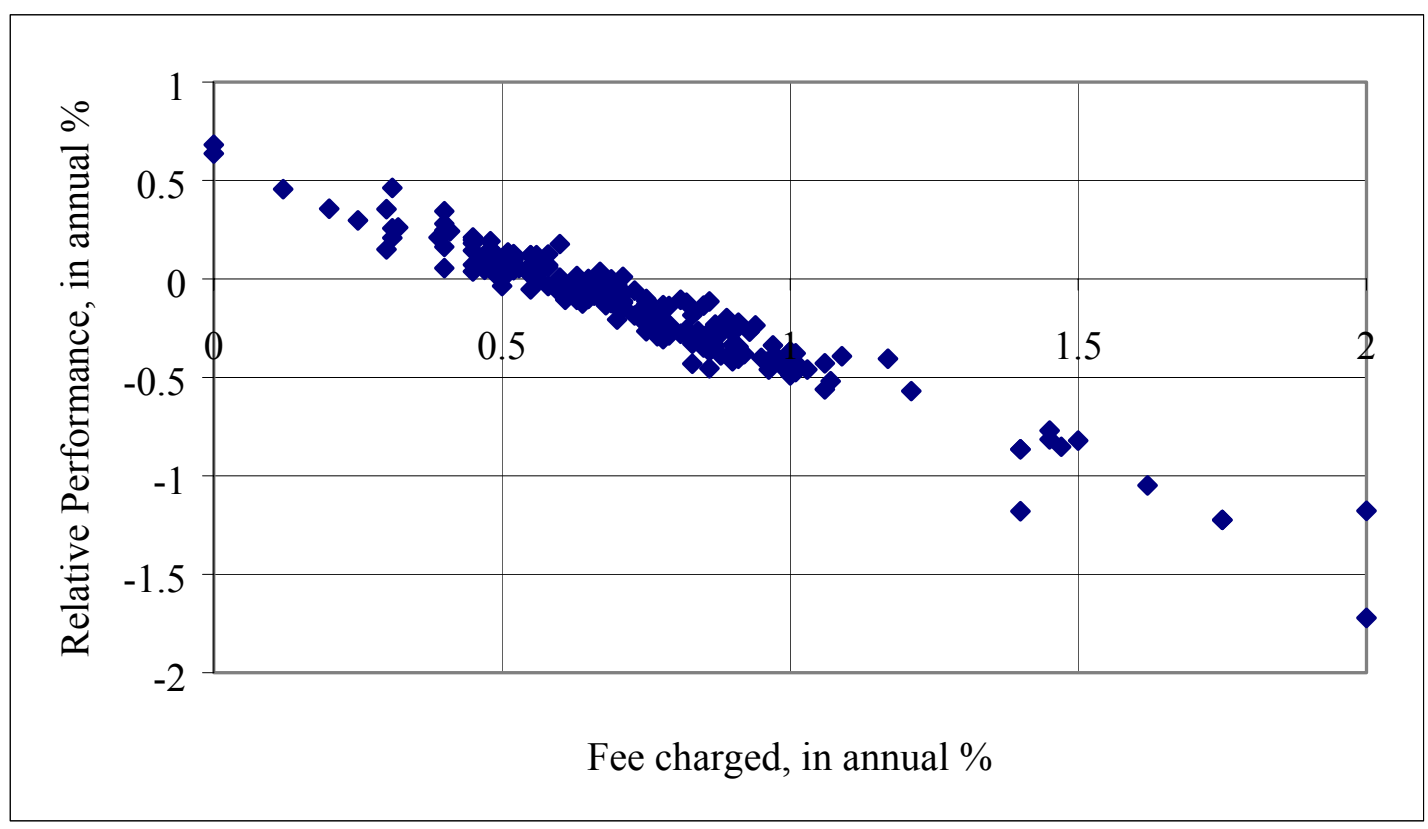

Figure 2. Excess FY96 return vs. FY96 fee. The excess return is the total return of the fund, minus the average total return of all Tier 1 and 2 retail money funds over the same weeks. 


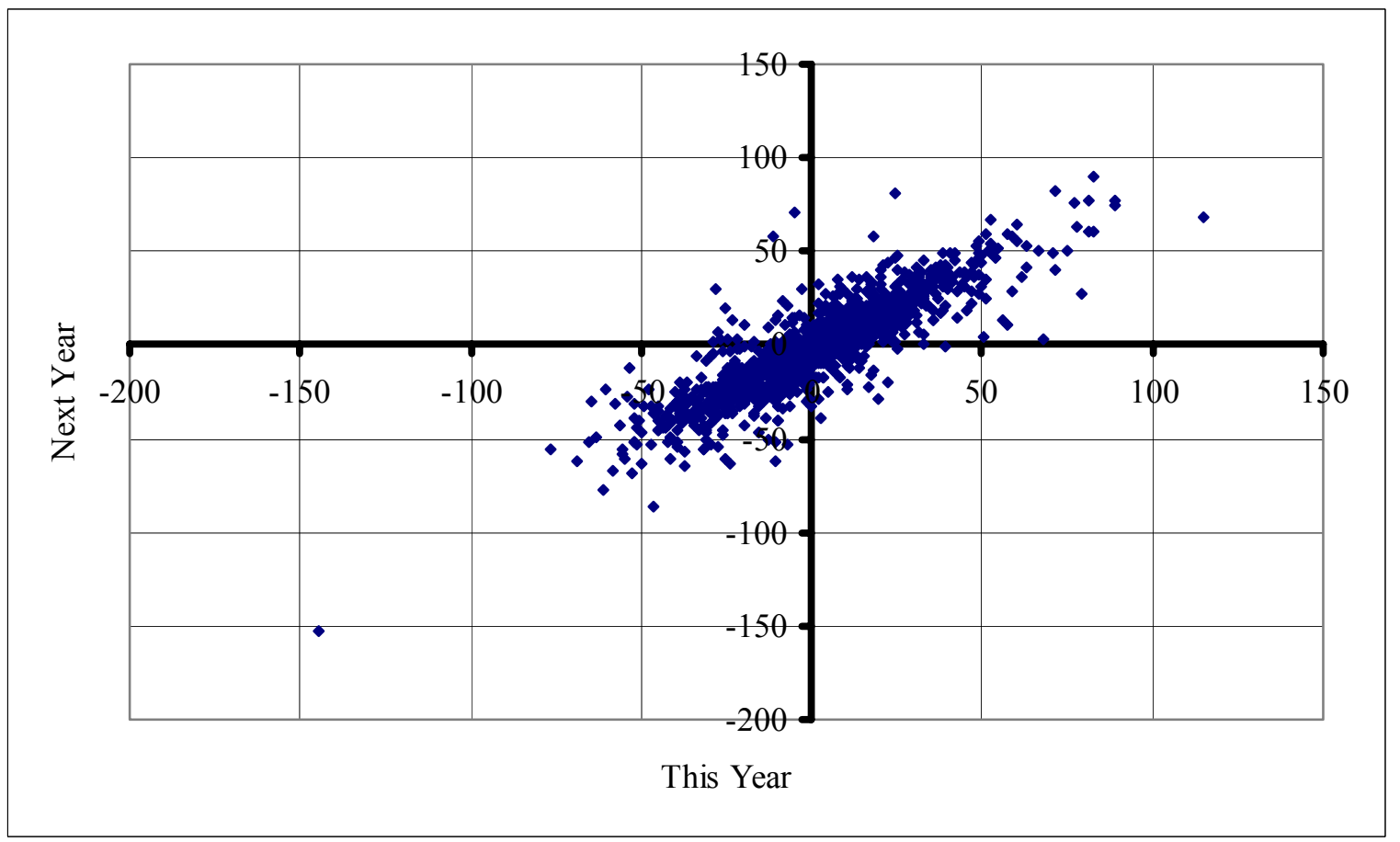

Figure 3. Performance persistence of Tier 1 and Tier 2 retail money funds. Excess return (relative to index of all funds) in one year compared to excess return in the next. In basis points.

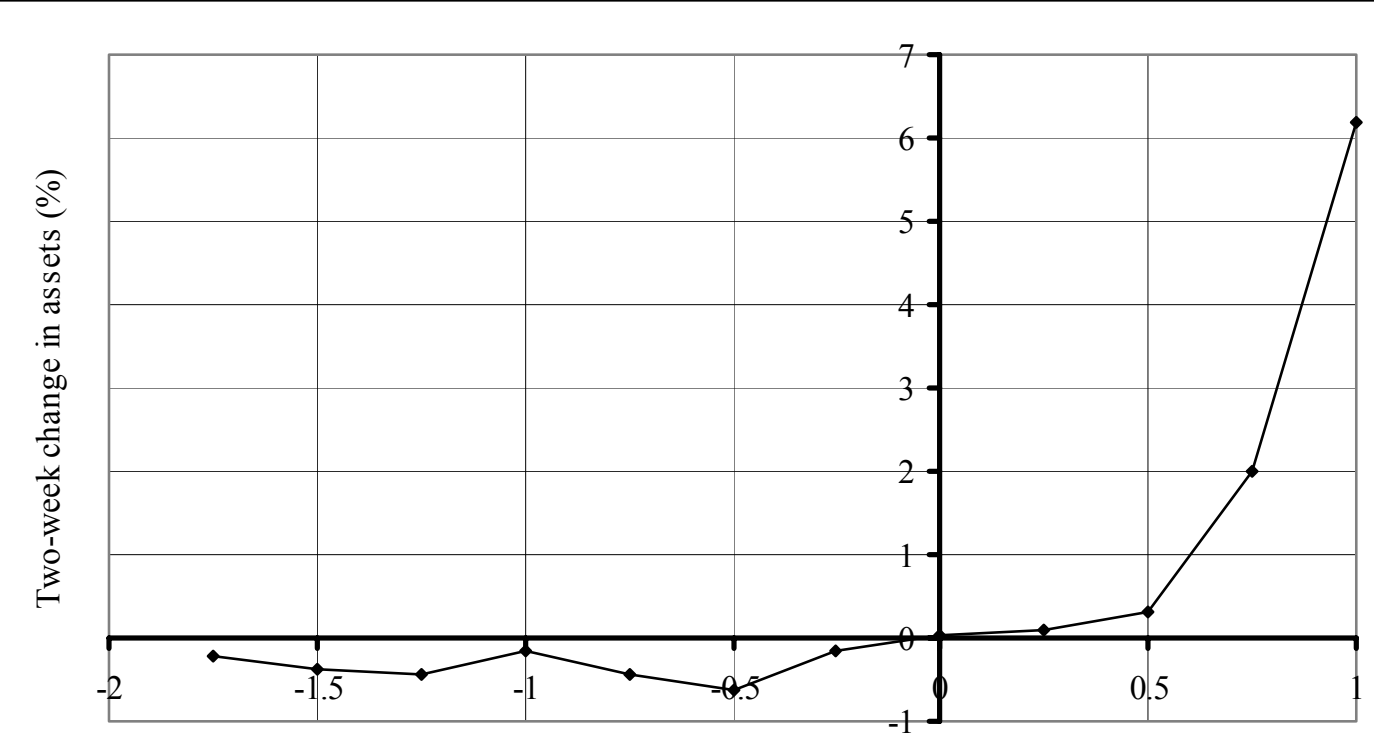

Upper bound of performance bin

Figure 4. Net two-week flow into money funds, sorted by past performance. Funds are sorted into $25 \mathrm{bp}-$ wide bins by their week $w$ performance, and the median percentage change in assets under management by week $w^{+}+2$, net of the change due to the funds' returns, is calculated for each bin. 


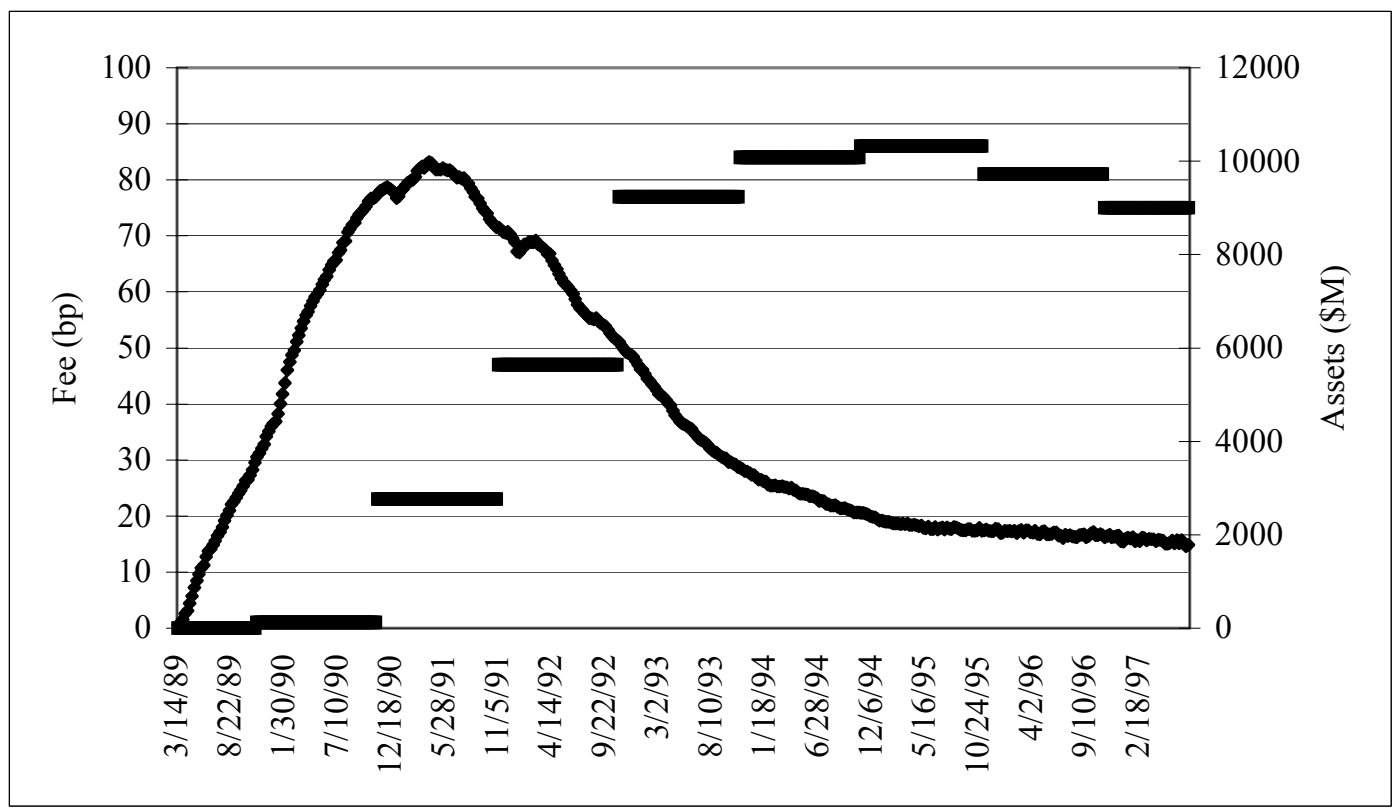

Figure 5. Fees and Assets of the Dreyfus Worldwide Dollar Fund. Fees (disjoint lines) are on the left axis, and assets under management (continuous line) are on the right axis.

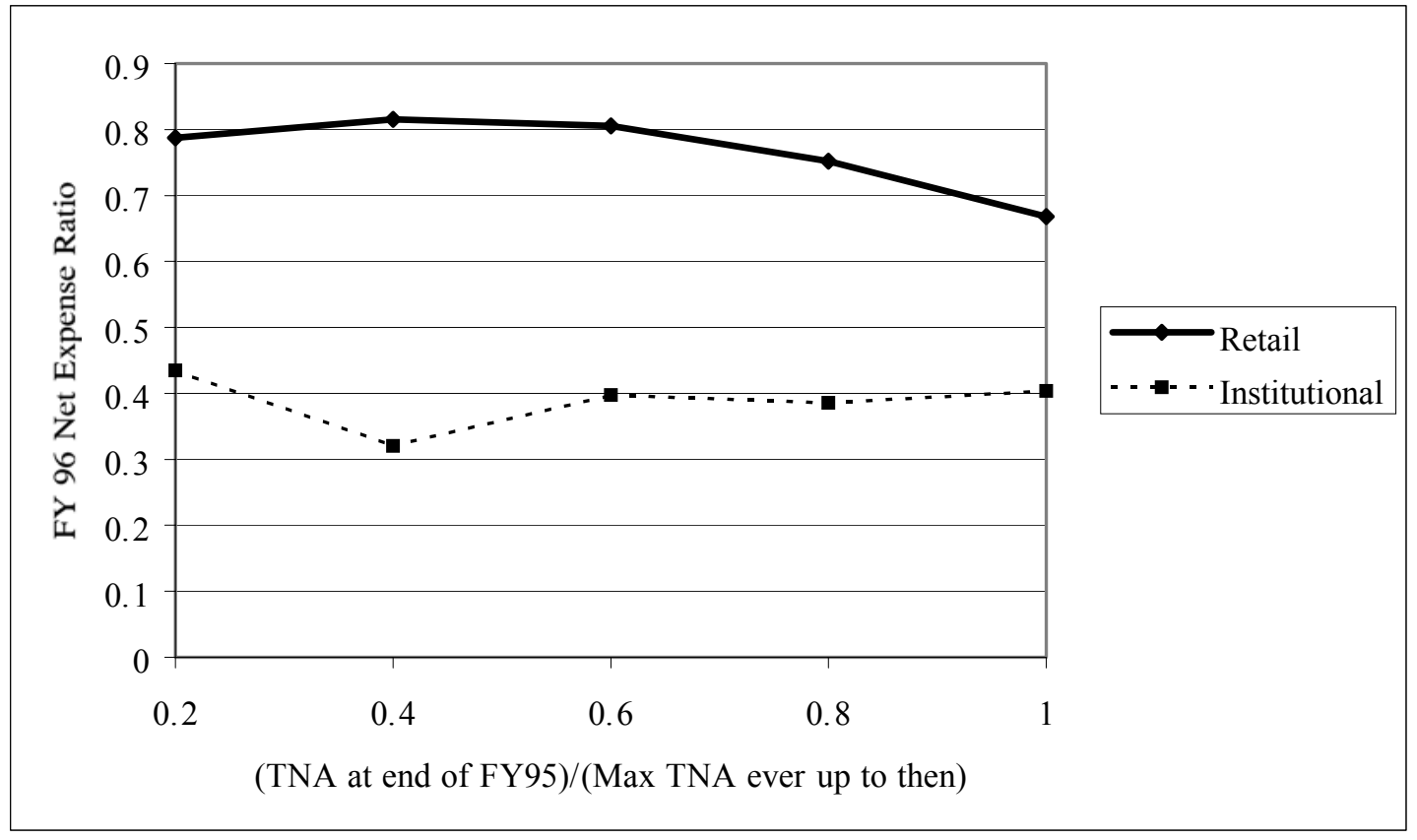

Figure 6. Relative yield $v s$. Attrition of Money Funds. Funds are sorted into five bins by their attrition over the first 478 weeks of the MFR sample period, and the average annualized yield within each bin over the terminal 26 weeks of the period is calculated. 


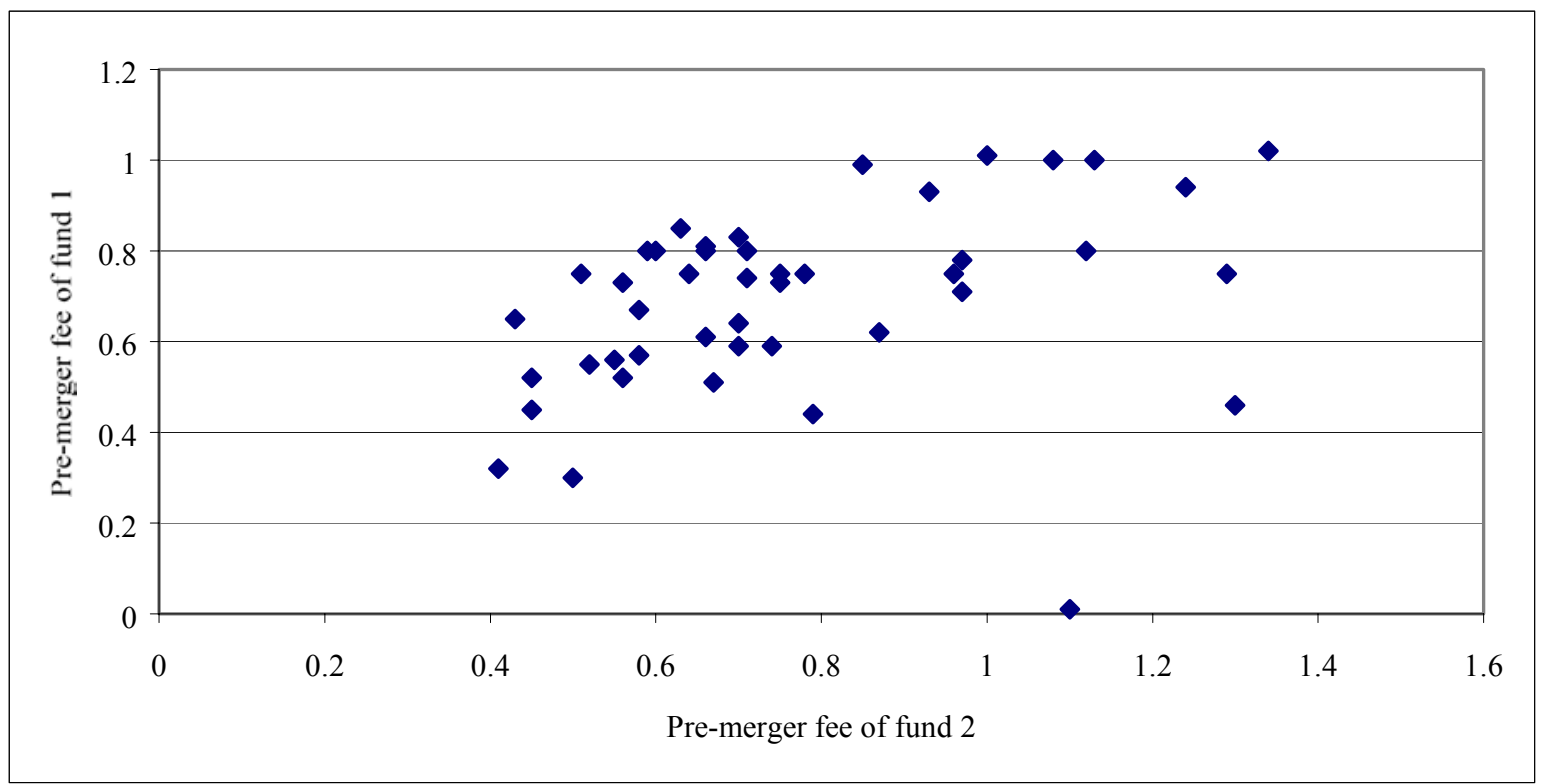

Figure 7. Fees charged by Tier 1 and Tier 2 retail money funds in their last fiscal years before the merger, in annual percent. 